Revue de sciences sociales sur les arts, la culture et les idées

\author{
$3 \mid 2018$ \\ Questions d'in-disciplines
}

\title{
Method Over Genre
}

Ways of Learning as a Source of Diversity in Making and Thinking About Music

Une partition non musicale. Les modes de transmission comme source de diversité des manières de faire et de penser la musique

Una partición no musical. Los modos de transmisión como fuente de diversidad de las maneras de hacer y de pensar la música

\section{Rémi Deslyper}

Translator. Delaina Haslam

\section{OpenEdition}

\section{Journals}

Electronic version

URL: http://journals.openedition.org/bssg/301

DOI: $10.4000 /$ bssg.301

ISSN: 2490-9424

\section{Publisher}

Presses universitaires de Vincennes

Electronic reference

Rémi Deslyper, "Method Over Genre", Biens Symboliques / Symbolic Goods [Online], 3 | 2018, Online since 15 October 2018, connection on 04 March 2021. URL: http://journals.openedition.org/bssg/301 ; DOI: https://doi.org/10.4000/bssg.301 
Une partition non musicale

Les modes de transmission comme source de diversité des manières de faire et de penser la musique

\section{Method Over Genre}

Ways of Learning as a Source of Diversity in Making and Thinking About Music

Rémi Deslyper

traduction | translation

Delaina Haslam

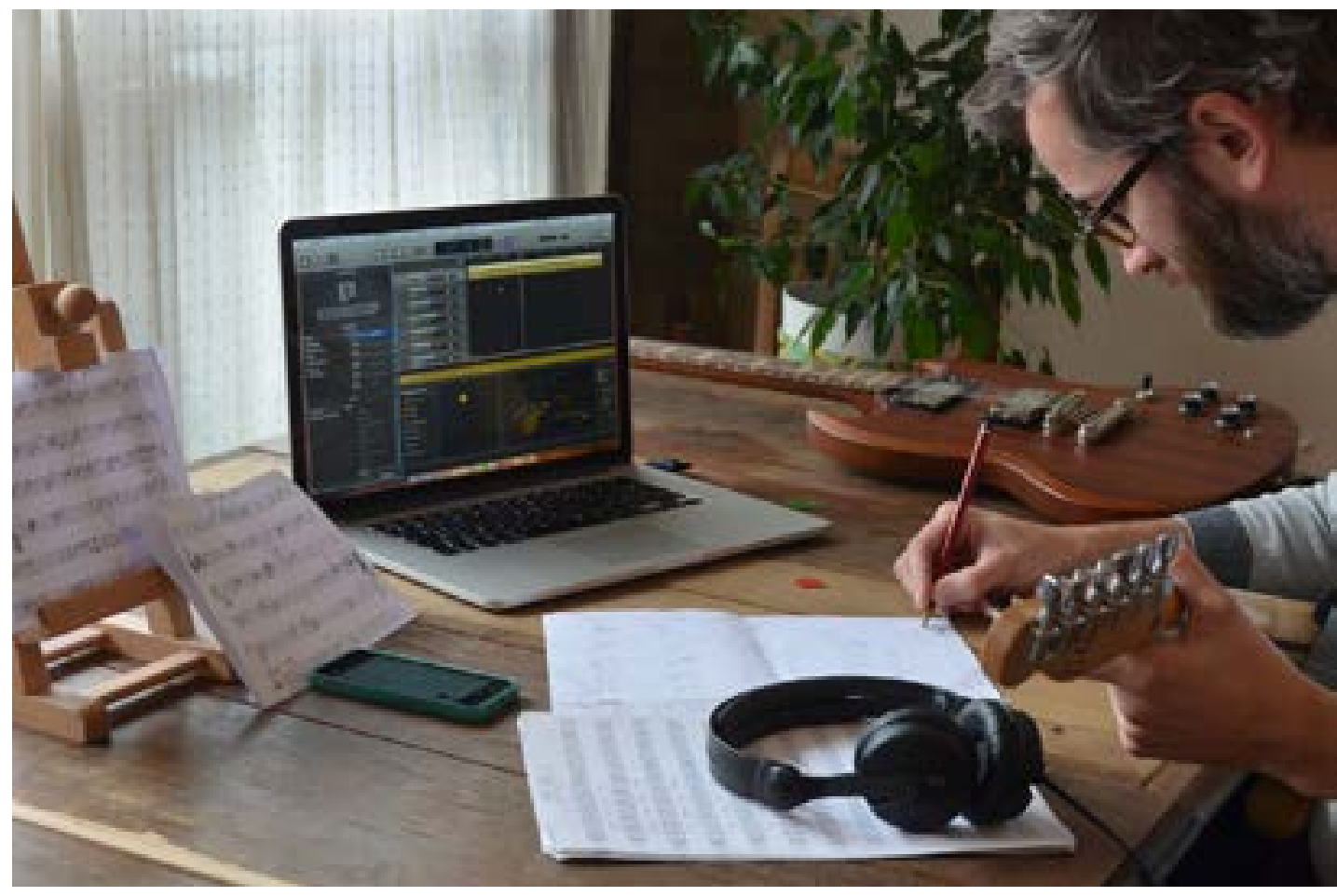

Illustration 1. Un élève guitariste faisant de la musique. / A guitar student making music. 
Dans la majorité des études sociologiques portant sur les musiciens de musiques «populaires » contemporaines, ceux-ci sont appréhendés en référence directe à la notion de genre musical. $Y$ sont analysés, et donc distingués, les « rockeurs », les « rappeurs », les « jazzmen », etc., les genres musicaux constituant alors, explicitement ou implicitement, le principe essentiel, quasi naturel, de division entre les musiciens. S'il est indéniable que ces catégories participent de la structuration objective (à travers leurs médias, leurs « scènes ", leurs conventions...) et subjective de l'univers socio-musical, elles donnent cependant parfois lieu à des analyses méthodologiquement discutables (nous reviendrons plus loin sur ce point). Catégories de perception de la musique socialement construites et socialement situées qui préexistent à l'analyse sociologique, les genres musicaux nous semblent en fait relever d'une sorte de sens commun musical peu interrogé par la sociologie (Perrenoud 2012a ; Legon 2016) et dont la domination dans le champ scientifique tend à masquer d'autres lignes de clivages entre les musiciens. C'est justement une autre ligne de partage entre musiciens que nous souhaitons mettre au jour dans cet article, une partition que nous avons qualifiée de non musicale dans la mesure où elle ne relève pas d'un principe musicologique, mais du clivage opéré par le mode de transmission de la pratique ${ }^{1}$.

« [T]oute sociologie, écrivent Guy Vincent, Bernard Lahire et Daniel Thin, quels que soient son objet de recherche, son

1 À cet égard, cet article précise, complète et prolonge des réflexions engagées dans une précédente publication (Deslyper, 2009).
In the majority of sociological studies, musicians of contemporary popular music are understood in direct reference to the concept of musical genre. They are analysed, and therefore differentiated as "rock," "rap," "jazz" musicians, and so on-in such a way that music genres constituteexplicitly or implicitly - the essential, almost natural, principle of division between musicians. While it cannot be denied that these categories form part of an objective (through the media, different "scenes," conventions, and so on) and subjective structuring of the socio-musical world, they can sometimes lead to methodologically questionable analysis (I will return to this point later). Music genres-as socially constructed and situated categories for the perception of music that pre-exist sociological analysis - appear to be part of a sort of common notion of music that has been little investigated by sociology (Perrenoud 2012a; Legon 2016), and whose domination in the scientific field tends to hide other dividing lines between musicians. But in this article I would like to reveal an alternative divide between musicians-one I class as non-musical insofar as it is not a musicological theory, but rather a divide in terms of the way in which the practice is transferred ${ }^{1}$.

"All sociology," write Guy Vincent, Bernard Lahire, and Daniel Thin, "whatever the research focus or field of inquiry should

1 In this regard, this article refines, completes, and prolongs the thinking begun in a previous publication (Deslyper 2009) 
terrain d'investigation devrait être aussi une sociologie de l'éducation tant une pratique n'est compréhensible que par rapport au mode d'appropriation (ou mode d'acquisition) de cette pratique et par rapport à l'histoire des êtres sociaux qui l'effectuent »(Vincent, Lahire, Thin 1994 : 38). Appliqué à la pratique musicale, cela signifie que la manière de faire et de penser la musique est directement liée à la façon dont elle a été transmise. De ce fait, la diversité des modes de transmission peut logiquement être envisagée comme un facteur de division objective entre les musiciens. Cette idée que les modes d'apprentissage constituent une ligne de clivage au sein de la pratique musicale n'est pas neuve et a déjà été évoquée dans quelques travaux sociologiques, sans pour autant faire l'objet d'une analyse spécifique. Ainsi, c'est plus ou moins ce qu'entendait, il y a plus de 25 ans, JeanLouis Fabiani, lorsqu'il se demandait si l'institutionnalisation du jazz, et notamment de son enseignement, n'aboutirait pas à « la mise en place de nouvelles hiérarchies et de nouvelles stratégies de distinction » entre les musiciens (Fabiani 1986 : 243). Plus récemment, étudiant le cas, atypique, d'un musicien d'orchestre symphonique issu d'un apprentissage autodidacte du jazz, Bernard Lehmann note que « tout ou presque distingue un jazzman autodidacte d'un musicien classique passé par le plus jeune âge par le "moule" des conservatoires : ils ne perçoivent pas la musique de la même façon, ne la pénètrent pas de la même façon et ne la travaillent pas davantage de la même façon » (Lehmann 2002 : 126). Enfin, différents travaux ont déjà souligné, de manière assez ponctuelle, l'existence de différences dans les manières de faire et de penser les musiques «populaires » also be a sociology of education since a practice can only be understood in relation to its forms of appropriation (or acquisition) and to the history of social beings who carry this out" (Vincent, Lahire, Thin 1994: 38). Applied to music playing, this means that the manner of making and thinking about music is directly related to the way in which this is transmitted. The diversity of transmission methods can thereby be considered logically to be an objective dividing factor between musicians. This idea that learning methods constitute a dividing line within music playing is not new, and has already been referred to in some sociological works, and yet it has not been the subject of specific analysis. This was thereby more or less Jean-Louis Fabiani's intention more than twenty-five years ago when he wondered if the institutionalization of jazz, and in particular of its teaching, would lead to the "establishment of new hierarchies and distinction strategies" between musicians (Fabiani 1986: 243). More recently, studying the atypical case of a symphony orchestra musician who had been self-taught via jazz, Bernard Lehmann noted that "a self-taught jazz artist differs from a classical musician who has been through the 'mill' of music conservatoires from a very young age in almost every way: they do not perceive music in the same way, do not immerse themselves in the same way, and do not work at it in the same way" (Lehmann 2002: 126). Finally, various works have already stressed, on a rather sporadic basis, the existence of differences in the ways of Making and thinking about contemporary popular music depending on the method of transmission (Coulangeon 1999; Perrenoud 2007, 2012b; Brandl 2009). These considerations require elaboration via more specific studies that would lead to an explanation of the 
contemporaines selon le mode de transmission (Coulangeon 1999 ; Perrenoud 2007, 2012b ; Brandl 2009). Ces réflexions appellent à être approfondies par des études plus spécifiques permettant de rendre compte du clivage opéré par la diversité des formes de transmission sur les manières de faire et de penser la musique.

L'institutionnalisation relativement récente, et encore en cours, de l'apprentissage des musiques « populaires » contemporaines constitue une situation propice à l'étude de cette partition. On assiste en effet, depuis maintenant un peu plus d'une trentaine d'années en France, à une institutionnalisation croissante de l'enseignement des pratiques musicales «populaires » contemporaines qui a commencé avec l'entrée du jazz dans les écoles de musique publiques entre la fin des années 1970 et le milieu des années 1980 (Coulangeon 1999) et s'est poursuivie par l'arrivée des «musiques actuelles » à la fin des années $1990^{2}$. En effet, si c'est en 1980 que se crée le premier département de « musiques actuelles », à l'époque baptisé " rock », dans une école de musique publique, cette initiative reste alors relativement isolée. En dehors de l'émergence de quelques écoles de musique privées et associatives, ce n'est qu'à la fin des années 1990 que les « musiques actuelles »

2 Terminologie institutionnelle adoptée par les pouvoirs publics français au début des années 1980, les « musiques actuelles » regroupent l'ensemble des musiques « populaires » : le « jazz », la « chanson », le « rock», le « rap» et la « techno », mais aussi la « variété » et les « musiques traditionnelles ». Dans l'enseignement musical institutionnel, l'appellation exclut les « musiques traditionnelles » et le « jazz », qui possédaient déjà leurs propres départements d'enseignement quand les « musiques actuelles » ont fait leur divide created by the diversity of forms of transmission on the various ways of making and thinking about music.

The relatively recent and ongoing institutionalization of the teaching of contemporary popular music presents a situation conducive to the study of this divide. Indeed, over the past just over thirty years, we have seen an increasing institutionalization of contemporary popular music teaching in France that began with the introduction of jazz into public music schools between the end of the 1970s and the mid1980s (Coulangeon 1999), and continued with the arrival of musiques actuelles (modern/new music) at the end of the $1990 \mathrm{~s}^{2}$. Although the first public music school department for musiques actuelles-then called "rock"-was created in 1980 , this remains a relatively isolated initiative. Apart from the emergence of a few private music schools and schools run by non profit associations, it was not until the end of the 1990s that current music really began to be established in state-approved music teaching establishments, with the creation in 1998 of a teaching certificate for musiques

2 Musiques actuelles is institutional terminology adopted by the French administration at the beginning of the 1980s to refer to all forms of popular music: jazz, chanson, rock, rap, and electronic music, and also pop and "traditional music." In institutional music teaching, the term excludes traditional music and jazz, which already had their own teaching departments when musiques actuelles was introduced into music schools. For the sake of simplicity, I shall employ the term musiques actuelles in the rest of the article. 
commencent véritablement à intégrer les établissements d'enseignement musical agréés par l'État, avec la création, en 1998, du certificat d'aptitude d'enseignant de « musiques actuelles » et celle, en 2000, du diplôme d'État d'enseignant de " musiques actuelles ». On compte ainsi, en 2008, 76 classes ou départements d'enseignement de « musiques actuelles » dans les 380 établissements d'enseignement spécialisés contrôlés par l'État (François 2008). Ce développement des institutions d'enseignement des « musiques actuelles » offre l'occasion d'analyser l'effet de ce « nouveau » mode de transmission sur la manière de faire et de penser la musique et donc, plus largement, de tester l'hypothèse d'un clivage séparant les musiciens selon leur mode de transmission de

la pratique.

Pour rendre compte des effets produits par la diversité des modes de transmission nous reviendrons, dans un premier temps, sur le concept de forme scolaire afin de montrer comment ce mode de transmission peut être à l'origine d'une transformation du rapport à la pratique. Puis, après avoir présenté la méthodologie de cette recherche, nous montrerons, à travers trois aspects de la pratique, l'impact du passage par l'école de musique sur la manière de faire et de penser la musique des élèves. actuelles, and in 2000 of a national musiques actuelles teaching diploma. In 2008, there were thus seventy-six musiques actuelles classes or teaching departments in the 380 specialist teaching establishments under state control (François 2008). This development of musiques actuelles teaching institutions provides an opportunity to analyse the effect of this "new" transmission method on ways of making and thinking about music, and hence, more generally, to test the hypothesis of a divide between musicians according to method of transmission of the practice.

To explain the effects produced by the diversity of transmission methods, I will return, first of all, to the concept of school form in order to show how this may be behind a transformation in the relationship to playing music. Next, after having presented the research methodology, I will show the impact of the experience of music school-by referring to three aspects of the practice-on the way students do and think about music.

entrée en école de musique. Afin d'alléger le texte, la formule « musiques actuelles " sera utilisée sans guillemets dans le reste de l'article. 


\section{Institutionnalisation de l'enseignement, forme scolaire et diversité des rapports à la pratique musicale}

Pour comprendre en quoi l'institutionnalisation de l'enseignement des musiques « populaires » contemporaines peut aboutir à la constitution d'une ligne de clivage au sein de celles-ci, il nous faut revenir plus en détail sur les caractéristiques du concept de «forme scolaire ». La forme scolaire, ou mode scolaire de socialisation, telle qu'elle a été conceptualisée en 1980 par Guy Vincent, dans le prolongement des réflexions de Roger Chartier et Régis Bernard, souligne le caractère formalisé de l'apprentissage qui s'est progressivement développé en France à partir du $\mathrm{XVI}^{\mathrm{e}}$ siècle jusqu'à devenir prédominant aujourd'hui (Vincent 1980). Contre une conception continuiste de l'histoire de l'enseignement, Vincent montre que c'est à partir de cette période que l'apprentissage s'est, peu à peu, déroulé en un temps, un lieu et avec des règles qui lui sont propres ; l'apprentissage est devenu une activité sociale autonome, distincte des autres activités sociales. Le concept est ensuite retravaillé au début des années 1990 par Bernard Lahire, qui met en évidence le lien entre cette forme de transmission et la nature des savoirs qui y sont transmis ${ }^{3}$. La particularité de ce qui est enseigné au sein de la forme scolaire est d'être

3 « L'école et la pédagogisation des relations sociales d'apprentissage sont liés à la constitution de savoirs scripturaux formalisés, savoirs objectivés, délimités, codifiés [...]. Le mode de socialisation scolaire est donc indissociable de la nature scripturale des savoirs à transmettre : la formalité des savoirs et les formes de relations sociales au sein desquelles ils sont "transmis" sont profondément liés » (Lahire 1993 : 37, souligné par l'auteur)

\section{The Institutionalization of Teaching, School Form, and the Diversity of Relationships to Playing Music}

In order to understand how the institutionalization of contemporary popular music teaching can lead to the formation of a divide within the genre, we must return to the characteristics of the concept of "school form" in greater detail. School form, or the school method of socialization, as it was defined in 1980 by Guy Vincent in an extension of the thinking of Roger Chartier and Régis Bernard, emphasizes the formalized character of education that gradually developed in France from the sixteenth century and that is predominant today (Vincent 1980). Rather than a "continuist" understanding of the history of teaching, Vincent shows that it was during this period that education gradually developed its own time, place, and rules; it became an autonomous social activity, distinct from other social activities. The concept was then reworked from the beginning of the 1990s by Bernard Lahire, who revealed a link between this form of transmission and the nature of the knowledge transmitted within it ${ }^{3}$. What distinguishes what is taught within school form is that it is intrinsically linked to a formal relationship to the activity,

3 "School and the educationalization of social relations of learning are linked to the creation of formalized scriptural knowledge, knowledge that is objective set within limits, and coded [...]. The type of school socialization is therefore indissociable from the scriptural nature of knowledge to transmit: the formality of knowledge and types of social relations within which it is transmitted are profoundly linked" (Lahire 1993a: 37, emphasis added by the author.) 
tramé par un rapport formel à l'activité, en rupture avec toute finalité pratique immédiate ${ }^{4}$. Cette caractéristique de ce mode de transmission n'est alors pas sans effet sur les pratiques elles-mêmes, au-delà même de l'apprentissage. La scolarisation d'une activité originellement non fondée sur la logique scolaire aboutit en effet à modifier en profondeur son sens et sa forme. C'est ainsi, par exemple, que Pierre Bourdieu pouvait noter que les public schools anglaises du $\mathrm{XIX}^{\mathrm{e}}$ siècle ont profondément transformé les jeux populaires qu'elles venaient d'intégrer pour participer à l'émergence du sport au sens contemporain du terme, c'est-à-dire comme activité physique autonome qui constitue sa propre finalité :

Pour caractériser dans son principe cette transformation [opérée par la scolarisation des jeux populaires], on peut dire que les exercices corporels de l'« élite " sont coupés des occasions sociales ordinaires auxquelles les jeux populaires restaient associés (fêtes agraires par exemple) et dépouillés des fonctions sociales (et a fortiori religieuses) encore attachées à nombre de jeux traditionnels (comme les jeux rituels pratiqués en nombre de sociétés précapitalistes

4 Par exemple, Lahire a bien montré que l'apprentissage, à l'école primaire, de la langue écrite, lue et parlée, rompt avec l'utilisation ordinaire et contextualisée du langage par les enfants, et notamment ceux de milieux populaires : « L'enfant était dans son langage, il le tient désormais face à lui et l'observe, le découpe, le souligne, le classe, le range en catégories. II se servait du langage pour dire ou faire des choses, et en pouvait presque ignorer l'existence tellement sa présence était indissociable des situations, des objets, des autres, des intentions, des émotions, des actes. On lui fait désormais prendre conscience du langage en tant que tel, dans sa matérialité et dans son fonctionnement propre, et on ne lui apprend pas vraiment à s'en servir dans des contextes d'usage particuliers, mais à en découvrir les lois spécifiques de fonctionnement, à voir comment il sert 》 (Lahire $1998: 122$, souligné par l'auteur) devoid of any immediate practical aim ${ }^{4}$. This characteristic of this transmission method therefore has an effect on practices themselves, even beyond education. As an activity not originally based on academic logic is introduced into the school system, this indeed has the effect of deeply altering its meaning and form. Thus, for example, Pierre Bourdieu observes that in the nineteenth century English public schools greatly transformed the popular games they introduced so as to play a role in the emergence of sport in the contemporary meaning of the term, that is to say as an autonomous physical activity that constitutes its own aim:

To characterize this transformation briefly, that is, as regards its principle, we can say that the bodily exercises of the "élite" are disconnected from the ordinary social occasions with which folk games remained associated (agrarian feasts, for example) and divested of the social (and, $A$ fortiori, religious) functions still attached to a number of traditional games (such as the ritual games played in a number of pre-capitalist societies at certain turning points in the farming year). The school, the site of schole, leisure, is the place where practices endowed with social functions

4 For example, Lahire clearly demonstrates that primary education of written read, and spoken language breaks with the ordinary and contextualized language spoken by children, especially working-class children: "The Child was in its language, she now holds this in front of her and observes it divides it, emphasizes it, classifies it and arranges it in categories. The child previously used language to say or do things, and could almost ignore its existence, given how its presence was indissociable from situations, object denoted, other people, intentions, emotions, actions. She is now made to become conscious of language as such, in its materiality and its specific operation, and not really taught to make use of it in the context of particula usages, but rather to discover its specific laws of operation, to see how it serves its purpose." (Lahire 2011:102, emphasis added by the author). 
à certains tournants de l'année agraire). L'école, lieu de la skholè, du loisir, est l'endroit où des pratiques dotées de fonctions sociales et intégrées dans un calendrier collectif, sont converties en exercices corporels, activités qui sont à elles-mêmes leur fin, sorte d'art pour l'art corporel, soumises à des règles spécifiques, de plus en plus irréductibles à toute nécessité fonctionnelle, et insérées dans un calendrier spécifique. L'école est le lieu par excellence de l'exercice que l'on dit gratuit et où s'acquiert une disposition distante et neutralisante à l'égard du monde social, celle-là même qui est impliquée dans le rapport bourgeois à l'art, au langage et au corps : la gymnastique fait du corps un usage qui, comme l'usage scolaire du langage, est à lui-même sa propre fin. (Bourdieu 1984 : 177)

Plus récemment, la recherche de Sylvia Faure et MarieCarmen Garcia sur les effets des politiques publiques en faveur de la danse hip-hop aboutit à un constat assez similaire. Les sociologues montrent en effet que l'institutionnalisation de la danse hip-hop, qui passe notamment par une pédagogisation de son apprentissage, retravaille les dispositions mentales et corporelles engagées dans l'activité par les danseurs et amène à la création d'une nouvelle forme de hip-hop reposant sur un rapport plus formel à l'activité qui se manifeste notamment par un certain éloignement de la pratique des battles au profit du développement d'une danse chorégraphiée (Faure \& Garcia 2005). De même, la recherche de Julien Bertrand sur un centre de formation de football montre bien, sans que cela constitue son angle d'attaque principal, comment cette institution, relevant de la forme scolaire, modifie le rapport à la pratique que les apprentis s'étaient constitués dans le cadre d'un apprentissage moins formalisé (Bertrand 2008 : and integrated into the collective calendar are converted into physical exercises, activities which are an end in themselves, a sort of physical art for art's sake, governed by specific rules, increasingly irreducible to any functional necessity, and inserted into a specific calendar. The school is the site, par excellence, of what are called gratuitous exercises, where one acquires adistant, neutralizing disposition towards language and the social world, the very same one which is implied in the bourgeois relation to art, language and the body:gymnastics makes a use of the body which, like the scholastic use of language, is an end in itself. (Bourdieu 1993: 119-120).

More recently, research by Sylvia Faure and Marie-Carmen Garcia into the effects of public policies in support of hip-hop culture reaches a similar conclusion. They show, indeed, that the institutionalization of hip-hop dance, in particular via its incorporation into the education system, reworks mental and physical dispositions involved in the activity by dancers and leads to the creation of a new form of hiphop based on a more formal relationship to the activity, which is particularly illustrated by a certain distancing of the practice from hip-hop "battles" in favour of the development of choreographed dance (Faure \& Garcia 2005). Similarly, research by Julien Bertrand into a football training centre provides a good illustration, without this being his main focus, of how this institution-as part of school form-changes the relationship to the practice that trainees establish within a less formal framework of learning (Bertrand 2008: 318-395). From this perspective, and since-despite the aims of those 
318-395). Dans la perspective de ces réflexions et parce que, malgré l'ambition des acteurs de son institutionnalisation, l'enseignement des « musiques actuelles » relève bien de la forme scolaire (Deslyper 2013), on peut faire l'hypothèse que l'univers des pratiques musicales «populaires " contemporaines est bel et bien traversé par une division selon le mode de transmission, scolaire versus non scolaire, formel vs informel. La pratique des musiciens formés au sein d'une institution d'enseignement se caractériserait alors, sous certaines conditions sociales, par un rapport formel à l'activité musicale, où celle-ci constitue sa propre finalité, en rupture avec le rapport fonctionnel à la pratique, caractéristique de l'apprentissage informel, dans lequel l'activité répond essentiellement à des finalités immédiates et extra-musicales

(sociabilité, détente...).

Cependant, si l'école est emblématique de la forme scolaire, et donc du rapport formel à l'activité qui en découle, apprendre en dehors de l'école ne signifie pas nécessairement apprendre en dehors de la forme scolaire. Comme le rappelle Thin, « la prédominance du mode scolaire de socialisation se manifeste par le fait que la forme scolaire a largement débordé les frontières de l'école et traverse de nombreuses institutions et de nombreux groupes sociaux. » (Thin 1998 : 30) Dès lors, l'autodidaxie, entendue comme un apprentissage qui se déroule en dehors de l'institution scolaire ${ }^{5}$, ne s'oppose

5 “L'autodidacte n'apprend jamais "tout seul”, mais ses maîtres, ses guides, ses "sourciers", car il y en a toujours (même s'ils peuvent prendre diverses figures), ne sont pas les enseignants habilités par l'institution scolaire (Poliak $1992:$ : 30). responsible for its institutionalization-musiques actuelles teaching is certainly part of school form (Deslyper 2013), we can surmise that the world of contemporary popular music playing is greatly affected by a division along transmission method lines-academic versus non-academic, or formal versus informal. The practice of musicians trained within a teaching establishment is therefore characterized, under certain social conditions, by a formal relationship to musical activity, whereby the latter constitutes its own aim, unlike the functional relationship to playing music that is characteristic of informal learning in which the activity essentially responds to immediate and extra-musical aims (sociability, relaxation, etc.).

However, although school is emblematic of school form, and therefore of the formal relationship to the activity that stems from it, learning outside school does not necessarily mean learning outside school form. As Daniel Thin points out, "the predominance of the school method of socialization is manifested in the fact that school form has widely crossed the boundaries of school and spread into numerous institutions and social groups" (Thin 1998: 30). Accordingly, self-tuition, understood as learning that takes place outside the school establishment ${ }^{5}$, is not necessarily inconsistent with school form. The use of videos or manuals designed to teach music

5 “The self-taught person doesn't learn 'on his/her own,' but his/her masters, his/ her guides, his/her sources, who always exist (even if they can take different forms), are simply not the school-certified teachers" (Poliak, 1992:30).. 
pas nécessairement à la forme scolaire. Le recours à des vidéos ou à des manuels ayant pour objet l'enseignement de la pratique instrumentale et reposant, au moins en partie, sur une réflexion pédagogique relève aussi d'une mise en œuvre d'un rapport scolaire à la musique. Ainsi, on peut tout à fait être autodidacte, c'est-à-dire apprendre en dehors d'une institution d'enseignement, mais mobiliser la logique scolaire. Par commodité, nous utiliserons toutefois dans la suite de cet article les termes d'« autodidaxie » et d'« autodidactes » pour qualifier l'apprentissage et les instrumentistes ayant appris de manière informelle ou en tout cas moins formelle qu'au sein d'une institution d'enseignement musical.

Ni sociologie de l'art, ni sociologie de l'éducation. Les conditions du développement et du maintien d'une direction de recherche

Je dois reconnaître que le croisement des sociologies de l'art et de l'éducation à l'œuvre dans cet article, et plus largement dans la recherche doctorale dont il est issu, n'a jamais été pensé comme tel. Si j'ai rapidement eu à me situer par rapport à ces spécialisations de la discipline, qui s'impose assez largement dans l'état actuel du champ de la sociologie, ce travail n'a, dans sa réalisation, jamais été appréhendé à travers ces catégories. Critique sur le découpage de la sociologie par objets d'étude, j'ai toujours considéré cette recherche comme une étude sociologique de rapports différenciés au savoir. Le fait qu'elle porte sur des musiciens, loin de la définir, tient surtout à la configuration particulière des rapports au savoir qu'offrait alors l'univers des pratiques musicales " populaires » contemporaines suite à l'institutionnalisation, en cours, de son enseignement. Cette manière d'envisager la recherche ne vient évidemment pas de nulle part et une rapide auto-analyse me permet d'en identifier plusieurs facteurs. and based, at least partially, on pedagogic thinking is also the result of an implementation of an academic relationship to music. Thus, one can be entirely self-taught, that is to say taught outside a teaching establishment, but apply an academic approach. For convenience, however, we will use the terms "self-tuition" and "self-taught" to refer to informal learning and instrumentalists who have learnt in an informal manner, or at least less formally than those within a music teaching establishment.

Neither Sociology of Art nor Sociology of Education: Conditions of Development and Maintenance of a Branch of Research

Admittedly, the crossover of the sociology of art and the sociology of education found in this article, and more generally in the $\mathrm{PhD}$ research it originates from, was never conceived as such. Although I quickly had to position myself regarding these specializations of the discipline, which have far-reaching significance for the current state of the field of sociology, the realization of this work was never envisaged through these categories. Being critical of the breakdown of sociology into research subjects, I have always considered this work as a sociological study into various relationships to knowledge. The fact that it is about musicians, far from defining it, is above all linked to the particular configuration of relationships to knowledge that the world of popular contemporary music playing offers as a result of the ongoing institutionalization of its teaching. This way of envisaging the research has not, of course, come out of nowhere, and a quick process of self-analysis identifies several contributing factors. 
En premier lieu, cette conception de la recherche tient, logiquement, à ma formation à la recherche. À partir du Master, j'ai poursuivi ma formation en sociologie au sein du laboratoire du Groupe de recherche sur la socialisation (depuis dissout au sein du Centre Max Weber) dont les membres résistaient alors activement au découpage de la discipline par objets et thèmes de recherche (sociologie de l'école, sociologie de la famille, sociologie de l'art, etc.) et défendaient une pratique de la sociologie davantage caractérisée par ses questionnements centrés sur la notion de socialisation (Darmon 2007). Par ailleurs, plusieurs membres avaient travaillé la question du rapport au savoir porté par le mode scolaire de socialisation (Lahire 1993a, 1993b ; Thin 1998 ; Baudelot, Cartier, Détrez 1999 ; Faure 2000 ; Millet 2003 ; Faure \& Garcia 2005 ; Bertrand 2008), faisant de cette question un axe fort du laboratoire. Cette perspective de recherche, que j'ai pleinement intégrée, m'a alors amené à envisager sous cet angle mon expérience personnelle de l'univers de la pratique musicale : musicien autodidacte, j'ai pu voir la pratique de certains de mes camarades de jeu, eux aussi issus de l'autodidaxie, se transformer considérablement suite à leur passage par une école de «musiques actuelles ». J'ai ainsi pu voir dans l'émergence de ces écoles et départements d'enseignement le développement d'une instance socialisatrice à l'origine d'un clivage dans les manières de faire et de penser la musique des musiciens.

L'influence du laboratoire ne saurait cependant suffire à expliquer une direction de recherche. Dans un contexte de regroupements massifs des instances de recherche, au détriment de toute pertinence scientifique, et de baisse des moyens qui leur sont alloués, les laboratoires, à quelques exceptions près, ne sont plus en mesure de proposer un véritable encadrement scientifique de leurs chercheurs, et notamment de leurs doctorants. Aussi, cette direction de
First of all, this perspective is naturally related to my research training. From master's level, I pursued my sociology training at the Groupe de recherche sur la socialisation (the Socialization Research Group, which has since merged into the Centre Max Weber), whose members were strongly opposed at the time to the division of the discipline into research subjects and themes (sociology of school, sociology of the family, sociology of art, etc.), and supported a sociological practice based on inquiries into the concept of socialization (Darmon 2007). Moreover, several members had worked on the issue of the relationship to knowledge through the school method of socialization (Lahire 1993a, 1993b; Thin 1998; Baudelot, Cartier, Détrez 1999; Faure 2000; Millet 2003; Faure \& Garcia 2005; Bertrand 2008), making this issue a strong focus of the laboratory. This research perspective, which I have fully endorsed, has led me to view my personal experience of the world of playing music from this angle: as a self-taught musician, I have been able to observe the practice of some of my self-taught peers transform significantly following their experience studying musiques actuelles at a school. Similarly, through the emergence of musiques actuelles schools and departments, I have seen the development of an instance of socialization that is behind a rift in musicians' ways of making and thinking about music.

However, the laboratory's influence cannot fully explain the research focus. In the context of huge mergers of research bodies to the detriment of all scientific relevance, and on the basis of the resources allocated to them, laboratories, in nearly all cases, are no longer able to offer a truly scientific framework to their researchers, above all their PhD students. I would also add that it has only been possible to maintain and develop this research thanks to regular and insightful discussions with colleagues and friends from other institutions carrying out their own research into cultural 
recherche n'a pu être maintenue et alimentee que grâce aux discussions, aussi régulières qu'enrichissantes, avec des collègues et ami-e.s d'autres institutions menant aussi de leur côté des recherches portant sur des objets culturels dans la même perspective (Legon 2014 ; Eloy 2015). Je profite d'ailleurs de cet encadré pour les en remercier.

\section{Terrain et méthodes}

Ces analyses sont issues d'une thèse de doctorat de sociologie, soutenue en 2013, portant sur l'impact de l'institutionnalisation de l'enseignement des « musiques actuelles "sur les manières de faire et de penser la musique. Pour saisir cet effet de l'institution, le choix a été fait de comparer la pratique de musiciens avant et après leur entrée en école de musique. L'observation du décalage entre la pratique d'avant et celle d'après l'entrée en école de musique nous est en effet apparue comme un bon moyen de mettre au jour les caractéristiques de l'approche scolaire de la pratique et, par conséquent, le clivage qu'établissent les modes de formation, scolaire et non scolaire, dans l'univers des musiques «populaires » contemporaines. Différents travaux ont en effet déjà souligné que les établissements d'enseignement des pratiques musicales « populaires» contemporaines ne sont que rarement à l'origine du prime apprentissage de la pratique de leurs élèves. Ces derniers ne font le plus souvent qu'y poursuivre un apprentissage entamé à l'écart de toute institution scolaire. La pratique débute en effet généralement par un apprentissage informel (Green 2002), " dans un contexte où les frontières [...] entre apprentissage musical et sociabilité adolescente sont fortement brouillées » objects from the same perspective (Legon 2014; Eloy 2015). I would like to thank them for this.

\section{Field and Methodology}

This analysis is based on a doctoral thesis in sociology, defended in 2013, on the impact of the institutionalization of the teaching of musiques actuelles on ways of making and thinking about music. In order to assess the institutionalization effect, I chose to compare musicians' practice before and after attending music school. Observing differences in their practice before and after music school indeed appeared to be a good way to reveal the characteristics of the school approach to playing music and, as a consequence, the rift that training methods-either academic or non-academic-form in the contemporary popular music world. Various works have in fact already highlighted that teaching establishments of contemporary popular music rarely constitute their students' first experience of music learning, but provide a continuation of education that begins outside an academic institution. Indeed, they generally begin learning informally (Green 2002), "in a context in which the borders [...] between music learning and adolescent sociability are significantly blurred" (Perrenoud 2007: 33), that is to say without the instrumentalist being aware of learning. Also, observing differences between the practice before and after music school offers an opportunity to comprehend the divide between the two 
(Perrenoud 2007 : 33), c'est-à-dire sans que l'instrumentiste ait conscience d'apprendre. Aussi, l'observation du décalage entre la pratique d'avant et celle d'après l'entrée en école de musique offre la possibilité de saisir la rupture entre les deux formes de pratique, formelle ou fonctionnelle, selon le mode de formation, scolaire ou non scolaire. Dans cette optique, nous avons interrogé des élèves ayant commencé la pratique en tant qu'autodidactes, pour rendre compte de la transformation opérée par l'institution dans la manière de

faire et de penser la musique.

Les résultats présentés dans cet article reposent sur l'analyse de 40 entretiens réalisés auprès d'élèves guitaristes (34 hommes et une femme ${ }^{6}$ ), ou anciens élèves (5 hommes), inscrits dans le $3^{e}$ cycle $^{7}$ de deux établissements rhône-alpins d'enseignement des « musiques actuelles » agréés par l'État (une école publique et une école associative). Ce choix de deux établissements, en plus de donner accès à un plus grand nombre d'enquêtés, évite le biais d'une monographie portant sur un seul établissement possiblement spécifique, notamment en termes de partis pris pédagogiques. II s'agissait donc, à travers ce choix, de départiculariser l'analyse pour pouvoir prétendre à une certaine montée en

6 Sur les inégalités de sexe au sein des musiques «populaires » contemporaines, nous renvoyons au travail de Philippe Coulangeon et Hyacinthe Ravet (2003).

$7 \quad$ Le $3^{\text {e }}$ cycle correspond au plus haut degré de l'enseignement institutionne des «musiques actuelles ». Appelé aussi, de manière plus ou moins officielle, cycle « professionnel », il s'étale sur 2 à 3 ans, à raison de 300 à 888 heures d'enseignement annuelles selon les années et les établissements, et accueille des élèves possédant déjà un certain niveau de pratique (l'accès à ce cycle fait l'objet d'une sélection sur audition). forms of practice-formal and practical-depending on type of training, whether academic or non-academic. From this perspective, I interviewed students who had begun playing in a self-taught capacity so as to observe the transformation in the way of making and thinking about music that is affected by the institution.

The results presented in this article are based on analysis of 40 interviews conducted with guitar students (34 men and 1 woman ${ }^{6}$ ), or former students (5 men), in the "third cycle"7 of two state-approved musiques actuelles teaching establishments in the Rhône-Alpes region (one state school and one run by a non profit association). The choice of two establishments, as well as giving access to a greater number of respondents, avoids the bias of a monograph on a single potentially specific establishment, especially in terms of pedagogic bias. This choice was therefore a matter of making the analysis less specific to aspire to a certain increase in its general relevance. The interview questions were therefore built around elements

6 Regarding gender inequality in contemporary popular music, I refer to the work of Philippe Coulangeon and Hyacinthe Ravet (2003).

7 French music schools comprise three "cycles" that represent 8 to14 years of study. Also referred to-both informally and formally-as the "professional" cycle, this stage lasts 2-3 years of 300-888 teaching hours depending on the year and the establishment, and welcomes students who have already attained a certain level of playing (admission to this cycle depends on selection via an audition). 
généralité. La grille d"entretien portait alors sur les éléments (manière de tenir l'instrument, morceaux joués, lieux de pratique, partenaires de jeu...) dont nous faisions l'hypothèse qu'ils étaient susceptibles d'avoir été modifiés par le passage en établissement d'enseignement musical et trahiraient ainsi l'intégration d'un rapport formel à la musique.

Parallèlement, dix entretiens ont aussi été menés avec des hommes guitaristes de musiques «populaires " contemporaines aux origines sociales variées ( $\mathrm{du}$ père ouvrier et de la mère nourrice au père ingénieur et à la mère enseignante d'histoire) n'étant jamais passés par une institution d'enseignement musical afin de ne pas se limiter aux déclarations rétrospectives des élèves. Interroger la pratique de guitaristes autodidactes nous est en effet apparu comme un moyen d'approcher la pratique qu'avaient les élèves avant leur intégration de l'école car, malgré tout ce qui peut les séparer (âge, ambition musicale, origine sociale...), les premiers temps de la pratique des élèves et la pratique actuelle des autodidactes interrogés ont néanmoins en commun de s'être déroulés en dehors de l'école de musique. En cela, la pratique des autodidactes pouvait être envisagée comme un point de référence d'une pratique non scolaire.

Par ailleurs, bien que la question de l'impact de l'école de musique nous semble dépasser les clivages entre instruments, le choix de s'intéresser à un instrument unique relève d'un souci de clarté de la démonstration ; les différences techniques entre instruments auraient nécessité de constantes adaptations, explications et précisions dans le cours du that I believed were likely to be affected by the experience of attending a music teaching establishment, and would therefore betray the assimilation of a formal relationship to music (such how the instrument is held; the pieces played, where music is played; playing partners, etc.).

At the same time, interviews were also carried out with 10 male contemporary popular music guitarists from various social backgrounds (from one who has a labourer father and mother who is a childminder to one whose father is an engineer and mother a history teacher) who have never attended a music teaching establishment, so as not to limit the study to students' retrospective statements. Looking at the way self-taught guitarists play indeed appeared to be a way of approaching the practice of students prior to entry into a school since, despite all that might separate them (age, musical ambition, social origin, etc.), students' first stage of learning and the current practice of the self-taught musicians interviewed share the fact of taking place outside music school. The practice of self-taught musicians could therefore be seen as a point of reference for non-academic music playing.

Furthermore, although I believe that the question of the impact of music school goes beyond the divisions between instruments, my choice to focus on a single instrument is related to a desire for clarity: the technical differences between instruments would call for constant adaptations, explanations, and clarifications throughout the argumentation that would 
raisonnement qui risquaient d'alourdir considérablement le propos. Le choix s'est donc porté sur la guitare, en partie en raison de son caractère emblématique (la guitare constitue en effet le symbole des « musiques actuelles »), mais aussi, et surtout, parce qu'elle se trouve être l'instrument qui attire, et de très loin, le plus d'élèves au sein des départements de « musiques actuelles » (les guitaristes étant 6 à 10 fois plus nombreux que les batteurs ou les bassistes, seconds groupes d'instrumentistes les plus nombreux dans les écoles

investiguées).

Enfin, avant de présenter les résultats de cette recherche, il est nécessaire de s'arrêter un instant sur les caractéristiques sociales de la population étudiée. L'effet de l'enseignement musical institutionnel sur le rapport à la musique et à sa pratique, et donc le clivage qu'il opère entre les musiciens, ne peut en effet se comprendre que rapporté à leur profil social ${ }^{8}$. II apparait alors que si la pratique de la guitare dans les registres musicaux « rock » « fonctionne plus comme un signe d'appartenance générationnelle que sociale » (Donnat 1996 : 112), le fait que cette pratique se prolonge dans le $3^{3}$ cycle d'une école de musique apparaît en revanche beaucoup plus situé socialement. Du fait du caractère socialement situé de l'ambition de devenir artiste (Bourdieu 1975) et du processus de sélection à l'œuvre à l'entrée des $3^{\mathrm{e}}$ cycles

8 Les conditions sociales de l'aspiration au métier de musicien de ces élèves ayant fait l'objet d'une analyse plus détaillée dans une autre publication (Deslyper 2018b), nous nous contenterons donc d'en présenter ici les principales caractéristiques. risk considerably weighing down the remarks. I therefore chose to focus on the guitar, partly because of its emblematic character (it is the quintessential symbol of current music), but also, and above all, because it is the instrument that by far attracts the most students in musiques actuelles departments (there are six to ten times more guitarists than drummers or bassists - the next largest instrumentalist groups in the schools investigated).

Finally, before presenting the results of this research, I will focus for a moment on the social characteristics of the population studied. The effect of institutional music teaching on the relationship to music and music playing, and therefore the division it creates between musicians, can only be understood in relation to the social profile of these musicians ${ }^{8}$. It appears, then, that while guitar playing in a "rock" context "functions more as a sign of generational belonging than of social belonging" (Donnat, 1996: 112), the fact that this practice extends into the third cycle of music school appears, on the other hand, much more socially situated. The socially situated character of the ambition to become an artist (Bourdieu, 1987) and of the selection process involved in admission into the third cycle at the establishments studied ${ }^{9}$ means that students on these courses represent a fairly

8 Since these students' social conditions of aspiration to the career of musician is the subject of more detailed analysis in another publication (Deslyper 2018b), I will concentrate on presenting the main characteristics here.

9 Because of the high number of candidates in relation to places (around 60 candidates for 4 to 10 places per year depending on establishment and year), admittance to 
des établissements étudiés ${ }^{9}$, les élèves de ces cursus se caractérisent en effet par une position assez centrale au sein de l'espace social de par leurs origines sociales et/ou leur capital scolaire. En considérant la position professionnelle la plus élevée dans la famille et sans prétendre engager un raisonnement statistique sur ces données, on peut remarquer que les élèves se répartissent en trois groupes. Une partie d'entre eux, majoritaire (26 individus sur les 40 élèves interrogés), est issue de la petite bourgeoisie « intellectuelle » (parents enseignants notamment). Un deuxième groupe (10 sur 40) compte des individus issus de milieux populaires en ascension par l'école (possédant un bac général et parfois même un titre universitaire). Enfin, dans une moindre mesure (4 sur 40), on trouve des élèves originaires des classes supérieures (parents médecin, ingénieur ou notaire) en déclin parce que n'ayant obtenu aucun titre universitaire. De plus, la quasi-totalité des élèves interrogés (tous sauf deux) ont obtenu un bac général et plusieurs ont suivi un parcours universitaire avant d'intégrer l'école de musique. Ces caractéristiques sociales et scolaires expliquent alors pourquoi les élèves tendent à adopter aussi massivement le rapport formel à la musique et à sa pratique, qui est celui défendu par l'école : ils se montrent en effet relativement ajustés à ce que l'école cherche à leur transmettre. central position within the social space in terms of their social origin, and/or educational capital. By considering the highest professional position in the family and without claiming to employ statistical reasoning on these data, we can say that students are divided into three groups. One group-the largest, containing 26 of the 40 students questioned, comes from the "intellectual" middle class (predominantly the sons and daughters of teachers). A second group (of 10 students) includes individuals from working-class backgrounds who are upwardly mobile via school (with a general baccalauréat and sometimes even a university degree). Finally, in a smaller capacity (4 out of 40 ) we find students from the upper classes-with doctor, engineer, or lawyer parents-on the decline on account of their not having obtained a university qualification. In addition, almost all of the students surveyed (all except two) have a general baccalauréat, and several have completed a university course before admission to music school. These social and educational characteristics then explain why students tend to also adopt to a considerable extent a formal relationship to music and playing music, which is that supported by the school: they show themselves to be in effect relatively adapted to what the school seeks to convey to them.

9 Du fait du nombre élevé de candidats par rapport aux places à pourvoir (une soixantaine de candidats pour 4 à 10 places par an selon les établissements et les années), l'entrée en $3^{\mathrm{e}}$ cycle d'enseignement des « musiques actuelles * fait en effet l'objet d'une sélection sur la base d'une audition musicale et d'un entretien avec les aspirants.

the third musiques actuelles teaching cycle is subject to selection on the basis of a musical audition and an interview. 
Précisons enfin que cette tendance lourde à la transformation de la pratique suite à l'intégration d'un établissement d'enseignement musical ne signifie bien évidemment pas que tous les élèves ont vu leur pratique se transformer sur tous les plans : de rares, et très ponctuelles, résistances ont pu se faire jour, mais le choix a été fait dans le cadre de cette recherche de se concentrer sur les logiques de pratique portées par les différents modes de transmission.

L'analyse des effets de l'entrée en école de musique fait alors apparaître que le mode de transmission est bien à l'origine d'un clivage entre les musiciens. En développant chez ces élèves un rapport formel à la musique et à sa pratique en rupture avec le rapport fonctionnel qu'ils adoptaient avant d'intégrer l'institution et qui reste celui des musiciens autodidactes, l'institution a pour ainsi dire créé un nouveau type de musicien qui coexiste, sans se confondre, avec l'ancien. Pour mettre en évidence cette partition induite par les modes scolaire et non scolaire de transmission dans les manières de faire et de penser la pratique musicale, nous nous focaliserons sur trois indices de la modification intervenue dans la pratique de musiciens depuis leur entrée en école de musique : le fait de savoir «travailler », de « comprendre » ce qu'ils jouent et de «s'ouvrir » à la pratique de différents genres musicaux ${ }^{10}$.

10 D'autres éléments (temps et lieux de pratique, relation aux partenaires de jeu et à la pratique collective...) de cette transformation du rapport à la musique et à sa pratique sont présentés dans une autre publication (Deslyper 2018a).
Lastly, I would like to point out that this strong transformation tendency in music practice following attendance of a music school does not, of course, mean that all students see their playing transform in every way: rare, very sporadic resistance occurs; but I chose in the context of this research to concentrate on the practical patterns that different transmission methods bring.

Analysis of the effects of attending music school implies, then, that the method of transmission is indeed the source of a division between musicians. By developing a formal relationship to music and to playing music in students that goes against the practical relationship they had adopted before attending the establishment-which remains intact in self-taught musicians - the establishment to some extent creates a new type of musician who coexists with, but is not confused with, the former. To shed light on this division between ways of making and thinking about music that is brought about by academic and non-academic transmission methods, I will focus on three signs of the change that takes place in musicians' practice following entry into music school: knowing how to "work"; "understanding" what they play; and "opening themselves up" to playing different genres of music ${ }^{10}$.

10 Other elements of this transformation of the relationship to music and playing music (time and location of practice, relationship to playing partners and to playing in a group, etc.) are presented in another publication (Deslyper 2018a). 


\section{Savoir «travailler » : d'une pratique de morceaux à une pratique d'exercices}

Distinction majeure aux yeux des élèves vis-à-vis d'autres musiciens mais aussi d'eux-mêmes, du musicien qu'ils étaient auparavant, l'entrée en école de musique leur a appris

$$
\text { à «travailler » : }
$$

« Ça, je sais que ça a changé [depuis mon entrée à l'école], c'est que je me suis rendu compte que même les grands groupes, ils ne sont pas arrivés là comme ça, y'a grave du travail derrière, tu vois. C'est des gars, ils n'ont pas claqué des doigts et c'est arrivé. Les gens le croient, mais c'est la partie invisible... Mais ça, ça a changé. Ça, je ne m'en rendais pas compte. Je me disais : "Ouais, bam, t'as des zicos, ça y est c'est parti”, tu vois ? Y'a de ça, forcément, si tu t'entoures bien, la preuve en est, mais après, il faut que les gonz ils sachent travailler. S'ils ne savent pas travailler, si tu ne sais pas travailler... Moi, je pense avoir appris à travailler aussi. » (Pierre-Emmanuel, 22 ans, guitariste depuis 7 années et inscrit à l'école depuis 2 ans.)

« Maintenant j'ai compris qu'il fallait travailler et ça change tout ! [rires] Parce qu'avant, ça m'est quand même arrivé de passer six heures sur ma guitare, tous les jours, mais sur les six heures, je devais être efficace pendant deux heures. Tout le reste c'était... Je pensais que je travaillais, mais en fait, je bougeaismesdoigtssurlemancheetçameservaitàrienquoi. 》 (Aurélien, 21 ans, guitariste depuis 10 années et inscrit en école de musique depuis 3 ans.)

" Je pense qu'avant, j'avais l'impression de bosser, mais, en y repensant, je me dis que je ne bossais pas tant que ça en fait. Maintenant je travaille vraiment. " (Florent, 24 ans, guitariste depuis 9 années et inscrit à l'école pour la $2^{\mathrm{e}}$ année.)

\section{Knowing How to "Work": From Playing Songs to Playing Exercises}

For students, a major difference-between themselves and other musicians, but also in relation to the musician they used to be-is that going to music school teaches them to "work":

"I know that that's something that's changed [since going to music school]-I've realized that even big groups didn't start out like that, there's serious work behind all that, you know. Those guys didn't just click their fingers and that was that. That's what people think, but it's the invisible bit [...] But that's what's changed. I wasn't aware of that before. I used to say to myself: 'Ok, you have musicians, that's it, you're there,' you know? Of course that can happen, if you get good people around you, there's evidence of that, but after, the dudes have got to know how to work. If they don't know how to work at it, if you don't know how to work at it... I think I've learnt to work hard, too." (Pierre-Emmanuel, 22, has played guitar for 7 years; attending music school for 2 years.)

"Now I know you have to work and that changes everything! [laughs] Because before, l'd even spend six hours playing my guitar, every day, but out of those six hours, probably two of those were worthwhile. The rest of the time it was ... I thought I was working, but in fact, I was moving my fingers down the neck, but it was doing nothing, you know." (Aurélien, 21, guitarist for 10 years; attending music school for 3 years.)

"Ithinkthatbefore, Ithought I wasworking, but, thinking back, I don't think I was working that hard, in fact. Now I really work." (Florent, 24, has played guitar for 9 years; in his second year of music school.) 
Savoir « travailler », c'est en réalité développer une nouvelle manière d'appréhender ce qui est joué, caractéristique du rapport formel à l'activité. Cela se donne particulièrement bien à voir dans la place que prennent désormais les exercices, pratique emblématique du «travail », dans leur activité musicale. Depuis leur entrée dans un établissement d'enseignement musical, il apparaît très clairement que les élèves sont passés d'une pratique musicale quasi exclusivement constituée de morceaux - généralement des reprises, parfois des compositions - à une activité centrée sur les exercices. Cette modification traduit plus largement une rupture avec le caractère immédiat du rapport fonctionnel à la pratique au profit d'un rapport formel à l'activité qui fait de la pratique sa propre fin.

Les morceaux constituent en effet la base de la pratique autodidacte : l'activité musicale consiste alors essentiellement en l'interprétation successive de différentes pièces :

Enquêteur. - Et comment ça se passe quand tu joues ? Tu fais quoi exactement?

Kevin (28 ans, guitariste autodidacte depuis 16 années). - Ben, je me dis : "allez, tu vas te faire 4, 5 morceaux de Pantera" par exemple. Je pars là-dessus, je joue, ça me prend 20, 30 minutes. Après, je me dis que je vais jouer des trucs un peu plus cool, son clair. Alors je vais passer sur des trucs... Ça peut être tout et n'importe quoi, ça peut être un morceau d'Hendrix enchaîné avec un blues de Steve Ray Vaughan.

Jean (27 ans, guitariste autodidacte depuis 11 ans). - Ce que je fais [quand je joue], c'est que je commence à reprendre deux, trois morceaux et j'enchaîne.
Knowing how to "work" is, in reality, developing a new way of understanding what one is playing, which is characteristic of the formal relationship to playing music. This can be seen especially in the importance given to exercises-an activity emblematic of "work" in music playing. Since starting at a music teaching establishment, it is evident that students have gone from exclusively playing songs-generally covers, sometimes compositions - to a practice centred on exercises. This change reflects a more general break with the immediate nature of a practical relationship to playing in favour of a formal relationship that constitutes its own aim.

Songs indeed form the basis of self-taught practice: musical activity, then, essentially consists in the successive interpretation of different pieces:

Interviewer. - And what happens when you play? You do what exactly?

Kevin (28, self-taught guitarist who has played for 16 years). - Well, I say to myself: "Go on, you're going to play four or five Pantera songs," for example. I go ahead, I play, this takes 20-30 minutes. After that, I decide to play something a bit cooler, with a clean sound. So I play a few things ... This can be anything and everything-a Hendrix song followed by some Stevie Ray Vaughan blues.

Jean (27, self-taught guitarist who has played for 11 years). - What I do [when I play], is that I start playing two or three songs, and I play them back-to-back. 
Cet intérêt pour les morceaux tend toutefois à disparaître avec l'entrée dans un établissement d'enseignement musical. Les élèves disent en effet en interpréter beaucoup moins qu'auparavant et privilégier désormais les exercices. Florent (24 ans, guitariste depuis 9 ans et inscrit à l'école pour la $2^{\mathrm{e}}$ année) explique ainsi que, depuis qu'il a intégré l'école de musique, les morceaux ont cédé la place aux exercices, qui sont même devenus sa «principale » activité musicale :

« C'est sûr qu'avant [d'entrer à l'école] je faisais plus de reprises, des trucs comme ca. C'est vrai que des fois, je passais une après-midi complète à jouer des morceaux [...] alors que ça maintenant je le fais vraiment plus [...]. Bon, je ne fais pas que des exercices non plus, mais c'est vrai que c'est devenu ma principale activité... [...] Alors jouer des morceaux, tu penses que c'est bien quand tu commences parce que c'est ce que t'as envie de faire, t'as pas envie de te faire chier à bosser des exercices pour au final savoir-faire que des exercices. Mais justement, c'est peut-être ça qu'i faut en fait. »

Il en va de même avec Paco, 19 ans, guitariste depuis 5 ans et inscrit en école de musique pour la première année, qui ne fait « plus que des exercices»:

« Je suis tombé un peu là-dedans [dans les exercices] cette année. Je me suis dit que je me mettais sérieusement à la musique. Du coup, je me suis rapidement dit : "Faut que je bosse, faut que je bosse, faut que je bosse." Et du coup, je suis tombé un peu dans un cycle assez bizarre. En fait, je [ne] fais plus de musique, je fais que des exercices maintenant.
However, this interest in songs tends to disappear on entry into a music teaching establishment. Indeed, students say that they play them much less than before and that they now favour exercises. Florent (24, has played guitar for nine years; in his second year of music school) thus explains that, since starting music school, songs have been replaced by exercises, which have even become his "main" musical activity:

"Certainly before [starting music school] I played more covers, things like that. It's true that l'd sometimes spend a whole afternoon playing songs [...], whereas I never do that anymore now [...]. Well, I don't just do exercises, but it's true that they've become my main activity [...] You think that playing songs is good when you start because that's what you want to do, you don't want to mess around doing exercises and end up being able to play nothing but exercises. But that's perhaps exactly what you must do.'

It is the same situation for Paco, 19, who has played the guitar for five years, is in his first year of music school, and plays "nothing but exercises":

"I've really gone straight into them [exercises] this year. I told myself that l'd turn to music seriously. And so I quickly said to myself: 'l've must work hard, l've must work hard, I've must work hard.' So I got into a bit of a weird cycle. In fact, I don't play music any more, I just do exercises now." 
Il convient de préciser que les exercices ne sont pas ici envisagés comme un moyen d'apprentissage ; ils constituent la pratique en elle-même font partie intégrante de la pratique des élèves. Jouer, pour les élèves, consiste essentiellement à faire des exercices. En cela les « musiques actuelles », telles qu'elles sont pratiquées par les élèves, ne diffèrent guère de ce qui s'observe dans les pratiques corporelles les plus institutionnalisées, artistiques et sportives notamment, où la majeure partie du temps de pratique relève de l'entretien et de l'amélioration de la technique, sous la forme d'exercices ${ }^{11}$.

À travers ce passage d'une pratique à base de morceaux à une pratique essentiellement composée d'exercices, c'est plus largement le basculement des élèves dans un rapport formel à la musique et à sa pratique qui se donne à voir. Les exercices, dont les gammes sont certainement l'exemple le plus emblématique, s'opposent en effet, par leur nature même, au caractère fini et immédiat du morceau, ils ne relèvent pas de la musique à proprement parler, au sens où ils ne sont pas destinés à être écoutés. Les élèves distinguent d'ailleurs toujours très clairement « faire de la musique » de « faire des exercices » (comme le dit Paco dans l'extrait d'entretien cité plus haut : «En fait, je [ne] fais plus de musique, je fais que des exercices maintenant $»)$, exprimant bien là le caractère incomplet des exercices. En faisant des exercices, les élèves

11 C'est par exemple le cas de la boxe à propos de laquelle Loïc Wacquant note que le boxeur « passe le plus clair de son temps hors du ring, à s'exercer inlassablement devant un miroir ou contre des sacs afin d'affiner sa technique, d'accroître sa puissance et d'aiguiser sa vitesse d'exécution, et hors salle à avaler des kilomètres de roadwork qui entretiennent son endurance [...] (Wacquant $1989: 51$ ).
We should note that exercises are not seen here as a way of learning; they constitute the practice in itself and are an integral part of students' playing. For students, playing music essentially means doing exercises. In this sense, playing musiques actuelles scarcely differs from what we can observe of student participation in the most institutionalized physical, artistic, and sports activities, in which most of the time devoted to them is spent maintaining and improving technique by doing exercises ${ }^{11}$.

In the process of this passage from a practice based on playing songs to one that essentially comprises exercises, what can be seen, more broadly, is the students' shift towards a formal relationship to music and playing music. Exercisesscales being the most emblematic example-indeed by their very nature go against the complete and immediate nature of songs and are not strictly 'music' in the sense that they are not intended to be listened to. Furthermore, students differentiate very clearly between "playing music" and "doing exercises" (as Paco says in the interview extract cited above: "In fact, I don't play music anymore; I just do exercises now"), which clearly expresses the incomplete nature of exercises. By doing exercises, students show that they make the activity an aim in and of itself, and that they do not regard it for its practical and immediate purpose: producing music. Doing

11 This is the case, for example, in boxing. Loïc Wacquant observes that boxers "spend most of their time out of the ring, exercise tirelessly in front of a mirror or against bags to refine their technique, increase their strength, and quicken their pace, and outdoors doing kilometres of 'roadwork' to maintain their endurance" (Wacquant 1989: 51). 
montrent alors qu'ils font de l'activité une fin en soi et qu'ils ne l'envisagent pas pour sa finalité pratique et immédiate : produire de la musique. L'exercice répond à une finalité plus lointaine : il est un investissement. C'est ce dont rend bien compte Julien (22 ans, guitariste depuis 6 ans et inscrit en école de musique depuis 2 ans) lorsqu'il explique : «Ce que je travaille en ce moment c'est plus des exercices de rythme, des gammes, des trucs comme ça. Des trucs qui feront que par la suite, je pourrai être plus libre ». L'exercice n'a pas d'intérêt en lui-même : ce n'est que « par la suite » qu'il porte ses fruits. II répond à un intérêt différé. Tout à l'inverse, c'est parce qu'ils sont pris dans un rapport fonctionnel à l'activité, parce qu'ils ne peuvent penser la pratique musicale en dehors de son intérêt immédiat, c'est-à-dire produire de la musique, que les autodidactes se refusent à effectuer des exercices. Ainsi, Yvan, 16 ans, guitariste autodidacte depuis un an, explique ne jamais faire d'exercices parce qu'il ne voit pas l'intérêt de jouer « des bouts de phrases les uns à la suite des autres qui ressemblent à rien ". Yvan démontre là son attachement à une pratique musicale qui répond à une finalité immédiate, à savoir que ce qui est réalisé sur l'instrument est appréhendé dans une perspective d'auditeur.

En passant d'une pratique instrumentale composée quasi exclusivement de morceaux à une pratique faite essentiellement d'exercices, les élèves rendent compte de leur appropriation du rapport formel à la musique et à sa pratique défendu par les établissements d'enseignement musical. La réalisation d'exercices implique en effet une certaine rupture avec la finalité pratique immédiate que exercises responds to a more distant aim: it is an investment. Julien (22, guitarist of 6 years; attending music school for 2 years) is aware of this when he explains: "At the moment I'm working more on rhythm exercises, scales, things like that. Things that mean that further down the line I can be freer." Exercises have no interest in themselves: it is only "further down the line" that they bear fruit. They correspond to a postponed interest. By contrast, it is self-taught musicians' practical relationship to playing music-because they cannot envisage the practice outside its immediate interest, in other words producing music-that is behind their refusal to do exercises. Thus, Yvan, 16, self-taught guitarist of one year, explains that he never does exercises because he does not see the point of playing "bits of phrases one after the other that do not mean anything." Yvan is demonstrating his dedication to music practice that responds to an immediate aim, namely that what is achieved with the instrument is understood from the perspective of a listener.

In moving from a music practice that is made up almost exclusively of songs to one that is essentially made up of exercises, students register their ownership of the formal relationship to music and playing music that is promoted by music teaching establishments. Doing exercises indeed involves a certain break with the immediate practical aim of the song, while-subject to the requirement of an immediate 
constitue le morceau, alors que, soumise à l'obligation de résultat immédiat, la pratique des autodidactes se compose principalement de morceaux.

\section{4. «Comprendre» la musique : l'exemple des accords}

Le basculement dans un rapport formel à la musique se manifeste aussi, et peut-être de la manière la plus évidente, par l'inscription des élèves dans un registre théorique d'appréhension de la musique. Dans les entretiens menés avec les élèves, ressort très nettement l'idée que l'intégration d'un établissement d'enseignement musical est à l'origine d'une forte théorisation de la musique. C'est, par exemple, ce que l'on retrouve dans les propos de Florent (24 ans, guitariste depuis 9 ans et inscrit en école de musique depuis 2 ans) : « Depuis que je suis à l'école, c'est sûr que je trouve que la musique, c'est plus intellectuel, dans le sens où il faut toujours anticiper, savoir ce que tu vas faire. T'es toujours en train de réfléchir et de... Ouais, de tout théoriser un peu dans ta tête. "Or, le développement de cette approche théorique de la musique n'est pas neutre ; il rend compte d'une transformation du rapport à la pratique.

Les premiers temps de pratique, en tant qu'autodidacte, se caractérisent en effet toujours par une certaine méconnaissance des fondements théoriques qui organisent et structurent la musique ${ }^{12}$. Pris dans une logique fonctionnelle,

12 Sur le processus historique de rationalisation de la musique occidentale, voir le travail de Max Weber (Weber 1997). result-the practice of self-taught musicians mainly consists of playing pieces.

\section{4. "Understanding" Music: The Example of Chords}

Students' shift towards a formal relationship to music is also apparent-and perhaps in a more obvious way-in their entry into a theoretical level of music learning. In the interviews conducted with students, the idea that going to a music teaching establishment leads to a strong theorization of music emerges very clearly. For example, we find this in comments made by Florent (24, guitarist of 9 years; attending music school for 2 years): "Since starting music school, I definitely find music more intellectual, in the sense that it's important to anticipate things and know what you're doing. You're always thinking and [...] Yeah, theorizing everything a bit in your head." Yet the development of this theoretical approach to music is not neutral insofar as it takes account of a transformation in the relationship to playing.

In fact, self-taught music playing is always accompanied at first by a certain lack of awareness of the theoretical bases that organize and structure music ${ }^{12}$. From a practical point of view, whereby what counts most are the social benefits

12 On the historical process of the rationalization of Western music, see the work of Max Weber (Weber 1958) 
dans laquelle ce qui compte est avant tout l'utilité sociale de ce qui est produit (créer l'ambiance, faire la fête, passer un bon moment entre amis...), les autodidactes n'ont pas d'intérêt à se pencher sur la logique propre de la musique ; sa seule réalisation leur suffit. Ils savent faire de la musique, mais ne savent pas ce qu'ils font, au sens où ils ne maîtrisent pas les principes théoriques qui régissent la musique. Pour ceux qui intègrent le cycle supérieur d'un établissement d'enseignement musical, la musique perd, en partie, ses fonctions sociales, et se met alors à exister en dehors de son exécution : elle devient un objet que l'on peut tenir devant soi et qui répond à des règles de fonctionnement interne, des principes musico-logiques. Pour le dire autrement, les musiciens passent d'une musique qui existait en tant que « faire » à une musique qui se présente aussi, et peutêtre surtout, comme un "savoir ». Aussi, désormais, ils « comprennent » la musique, selon une formule régulièrement entendue au cours de l'enquête et qui révèle un nouveau rapport, formel, à la musique, et les distingue, par la même occasion, de ceux qui ne la « comprennent » pas.

L'inscription des élèves dans une approche théorique de la musique depuis leur intégration d'un établissement d'enseignement musical se donne en premier lieu à voir à travers leur réappropriation, depuis une perspective théorique, de compétences acquises en dehors de l'école et qu'ils maîtrisaient jusqu'alors sur un mode pratique, comme c'est par exemple le cas de la réalisation d'accords. of what is produced (creating an atmosphere, partying, having fun with friends, etc.), self-taught musicians are not interested in focusing on the way music works in itself; it is enough for them simply to play. They know how to play, but they do not know what they do in the sense that they have not mastered the theoretical principles that govern music. For those who get a place in the highest cycle at a music teaching establishment, music loses its social function to some extent, existing instead separate from its execution: it becomes an autonomous object, and one which responds to internal rules of operating - to the principles of musical logic. To put it another way, musicians go from music existing in terms of "doing" to a music that also, and perhaps especially, presents itself as "knowledge." Additionally, they now "understand" music, according to a phrase heard regularly throughout the survey that reveals a new-formal-relationship to music, and that at the same time distinguishes them from those who do not "understand" it.

Students' entry into a theoretical approach to music from the point of starting at a music teaching establishment can be seen, first of all, through their reappropriation, from a historical perspective, of skills acquired outside school that they have mastered up until that point in a practical way, as is the case, for example, for playing chords. 
Technique emblématique de l'instrument, les accords sont à la base de la pratique guitaristique. La manière de les appréhender varie toutefois considérablement selon la logique, pratique ou théorique, dans laquelle s'inscrit l'instrumentiste. Ainsi, il apparaît qu'en passant du statut d'autodidacte à celui d'élève, les instrumentistes basculent d'une connaissance pratique des accords, dans laquelle ces derniers existent en tant que positions de doigts à réaliser sur l'instrument, à une connaissance théorique, dans laquelle les accords reposent sur un travail de construction « logique ».

Dans tous les entretiens, les élèves expliquent que, lors des premiers temps de pratique, les accords étaient appréhendés à partir de positions de doigts sur l'instrument connues par

cœur :

Aurélien (21 ans, guitariste depuis 10 ans et inscrit en école de musique depuis 3 ans). - Quand j'ai commencé, [...] je pensais plus [davantage] en positions [...]. Quand on commence, c'est vraiment plus simple à la gratte de penser en positions, parce qu'avec une position sur le manche, tu te déplaces partout en fait. C'est un truc propre à la gratte, qui fait aussi qu'on est des flemmards en harmonie, un truc comme ça, parce que les positions ça va.... C'est tellement simple et ça permet d'aller tellement vite qu'on se prend pas le chou à penser à ce qu'on est en train de faire.

Cette connaissance des accords uniquement à partir du positionnement des doigts sur le manche relève, pour parler comme Geneviève Delbos et Paul Jorion, d'un savoir procédural (Delbos \& Jorion 1984 : 11). En se saisissant des accords exclusivement à partir des positions de doigts, les
Chords underpin guitar playing, and are a symbolic technique for the instrument. However, the way to learn chords varies considerably according to the approachpractical or theoretical-followed by the instrumentalist. Thus it appears that, by going from self-taught to student status, instrumentalists shift from a practical knowledge of chords, in which the latter exist as positions for the fingers on the instrument, to a theoretical knowledge in which chords are built "logically."

In all interviews, students explain that when they first started playing, they learnt chords by memorizing finger positions:

Aurélien (21, guitarist for 10 years and attending music school for 3 years). - When I started, [...] I thought about positions more [...]. When you begin, it's really much simpler to think about the guitar in terms of positions, because with a position on the handle, you can get anywhere in fact. It's something unique to the guitar, which also makes us lazy when it comes to harmonies and things like that, because positions are easy enough [...]. It's so simple, and it allows you to go so fast you don't have a second to think about what you're doing.

This knowledge of chords using just the position of the fingers on the neck is a form of procedural knowledge, as Geneviève Delbos and Paul Jorion point out (Delbos \& Jorion 1984: 11). By learning chords only by the positioning of the fingers, instrumentalists are able to play them, but do not master the 
instrumentistes sont en mesure de les exécuter, mais ne maîtrisent pas la logique théorique qui les fonde (« on se prend pas le chou à penser à ce qu'on est en train de faire »).

En intégrant un établissement d'enseignement musical, les élèves tendent à envisager différemment les accords de guitare. Ceux-ci passent d'une réalité pratique, en tant que « faire », à une réalité plus théorique, plus « logique », en tant que « savoir ». C'est ce qu'expriment les élèves lorsque, dans les entretiens, ils disent désormais savoir « construire» les accords. L'idée de construction d'accords renvoie à la maîtrise d'une logique interne des accords, qui rompt avec l'approche par positions : les accords ne sont plus des éléments donnés, des positions de doigts connues par cœur qu'il s'agit de reproduire, mais des éléments construits, qui répondent à un principe « logique ", c'est-à-dire théorique, de construction à travers les notes (do, do\#, ré, ré\#, mi, fa...)

et les intervalles (les tons et demi-tons) qui les composent.

Ce basculement se manifeste dans la difficulté où se trouvent désormais les élèves de quantifier le nombre d'accords connus. Non qu'ils en connaissent trop pour être en mesure de les compter, mais surtout parce qu'un tel décompte n'est plus approprié au régime cognitif qui caractérise leur manière de les appréhender désormais. En effet, la question du nombre d'accords connus n'est pertinente que dans une approche pratique dans laquelle les accords correspondent à des positions de main mémorisées et quantifiables. Envisagée depuis la logique théorique, cette question n'a pas réellement de sens, dans la mesure où les accords sont appréhendés theoretical theory behind them ("you don't have a second to think about what you're doing").

Students tend to view guitar chords differently when they go to music school. They go from a practical reality of "doing" to a more theoretical or "logical" authority of "knowing." Students express this when they say in the interviews that they know how to "build" chords. The idea of building chords is linked to mastering their internal logic, which breaks with the "positions" approach: chords are no longer fixed elementsfinger positions learnt by heart that must be reproduced-but built, which respond to a "logical" - that is to say theoreticalprinciple of construction with notes (C, C\#, D, D\#, E, F, etc.) and intervals (whole tones and semitones) that make them up.

This shift manifests itself in the difficulty students now have in counting the number of chords they know. It is not that they know too many to count, but above all that such a calculation is no longer relevant to the cognitive system characteristic of the way in which they now understand them. Indeed, the question of the number of chords known is only relevant in a practical approach in which chords correspond to memorized and quantifiable hand positions. Seen via theoretical logic, this question does not really have meaning insofar as chords are understood as the product of "logical" reasoning. This is reflected in the responses received to the following question: 
comme le produit d'un raisonnement « logique ». C'est ce dont rendent bien compte les réponses obtenues à cette question :

Enquêteur. - Combien tu connais d'accords ?

Romain (25 ans, guitariste depuis 11 ans, qui a quitté l'école de musique il y a 4 ans après y être resté pendant 2 ans). - ...C'est-à-dire ? Combien je peux en jouer sur ma guitare ou combien j'en connais dans l'absolu?

- C'est quoi la différence ?

- Ben, dans l'absolu, je les connais tous, parce je sais les construire.

- Et avant, quand tu ne savais pas les construire, t'en connaissais un nombre déterminé ?

- Voilà. Au début, je devais en connaître 5, puis 20, 30 [...] mais après, voilà, tu sais construire tes accords. Je ne dis pas que c'est venu automatiquement, mais à un moment, tu comprends comment ça s'empile : tu comprends la logique.

Enquêteur. - Et là, à l'heure actuelle, tu connais combien d'accords ?Stéphane (24 ans, guitariste depuis 11 ans et inscrit en école de musique pour sa $3^{e}$ année). - Ben, je peux tous les jouer en fait. J'en sais rien [rires]. Peut-être une cinquantaine, quoi. En fait, après, ce n'est même pas question de connaître les accords, c'est plus question de dire : sur un accord, par exemple mineur 7 , tu sais que t'as une tonique, une tierce mineure, une quinte, une septième [...]. Je sais construire les accords. Je n'apprends pas les accords par cœur [...]. C'est transparent. Maintenant je sais très bien construire un accord.

À partir du moment où l'instrumentiste sait « construire » un accord, où il « comprend la logique » à l'origine de l'accord, il ne lui est plus vraiment possible de les quantifier et, quand bien même le pourrait-il, cette quantification n'aurait plus
Interviewer. - How many chords do you know?

Romain (25, guitarist for 11 years who left music school 4 years ago having attended for 2 years). - [...] Meaning? How many can I play on my guitar or how many do I know in total?

-What is the difference?

- Erm, in total, I know them all because I know how to build them.

- And before, when you didn't know how to build them, did you know a set number?

- Exactly. At the start, I must've known five, then twenty, thirty [...], but afterwards, that's it, you know how to build chords. I'm not saying that that happened automatically, but from a certain point you understand how to build them up: you understand the logic.

Interviewer. - And now, at this point in time, how many chords do you know?

Stéphane (24, has played guitar for 11 years; in his 3rd year of music school). - Erm, I can play them all in fact. I've no idea [laughs]. Maybe 50 or something. In fact, afterwards, it's not even a question of knowing chords, it's more about saying: for a chord, a minor 7 , for example, you know you have a tonic, a minor third, a fifth, a seventh [...]. I know how to build chords. I don't learn them by heart [...]. It's become very natural. I now know exactly how to build a chord.

From the moment when instrumentalists know how to "build" a chord, when they "understands the logic" behind the chord, it is no longer really possible for them to quantify them and, even if they could, this quantification would no longer have 
de sens. De même, c'est seulement dans le cadre d'une connaissance pratique des accords qu'un instrumentiste peut en oublier un. Les élèves expliquent en effet que, parce qu'ils ont compris le principe de construction des accords, ils n'ont plus besoin d'en retenir les positions. L'accord n'a plus à être mémorisé, il est déduit d'un raisonnement « logique » et ne peut donc pas être oublié.

\section{Jouer « de tout » : « ouverture » musicale des élèves et rapport formel à la musique}

Enfin, la différence de rapport à la pratique selon le mode de formation se manifeste aussi dans les choix stylistiques des morceaux interprétés par les élèves. Au cours des entretiens, les élèves présentent assez spontanément l'ouverture de leur pratique musicale à un large registre de genres (de fait, rarement plus de deux), le fait de jouer « de tout », comme un des grands changements opérés dans leur pratique depuis leur passage en institution d'enseignement musical. Si, à leur arrivée à l'école, leur pratique était souvent centrée sur un genre musical en particulier, les élèves nous expliquent s'être « ouverts » à l'interprétation d'autres genres musicaux. C'est, par exemple, le cas de Paco (19 ans, guitariste depuis 5 ans et inscrit en école de musique pour la première année) avec

le jazz :

« L'école m'a ouvert à pas mal de choses [...]. Au début, j'étais très ska rock, maintenant je me suis aussi tourné vers le jazz [...] Je ne connaissais vraiment pas le jazz l'année dernière, je connaissais vraiment pas du tout... Je ne savais pas du tout ce que c'était. » meaning. Similarly, it is only in the context of a practical knowledge of chords that an instrumentalist can forget one. Students explain, indeed, that since they have understood the principle of building chords, they no longer need to remember the positions. There is no longer a need to memorize the chord; it is deduced from "logical" reasoning, and cannot therefore be forgotten.

\section{Playing "a Bit of Everything": Students" Musical Beginnings and the Formal Relationship to Music}

Finally, the difference in the relationship to the practice according to type of training can also be seen in the stylistic choices of the pieces students play. During the interviews, students were fairly quick to talk about the way they began with a wide range of styles (in fact, this is rarely more than two) - playing "a bit of everything" - as one of the big changes in their practice since starting at a music teaching institution. Although, when they first go to a school, their playing is often centred on a particular genre of music, students say that they are "open" to playing other styles. For example, this was the case for Paco regarding jazz (19, guitarist for 5 years; in his first year of music school):

"School opened me up to a lot of things [...]. At the start, I was very into ska rock; now l'm more focused on jazz [...]. I didn't really know jazz last year, I hardly knew it at all [...] I didn't know what it was." 
Pour Florent (24 ans, guitariste depuis 9 ans et inscrit en école de musique depuis 2 ans), c'est la bossa nova qui symbolise son « ouverture » :

«En arrivant à l'école, je me suis dit qu'il valait mieux s'élargir plutôt que de se concentrer sur un truc particulier en fait. C'est plus par rapport à des styles... Une ouverture quoi... On a fait un concert de musique latine. Mon challenge au début de l'année dernière, je me suis dit que, si à la fin de l'année, j'arrive à jouer de la musique latine, à être calé en rythme et tout bien, je serai quand même vachement content de moi [...]. J'avais peur d'être trop à la rue et tout, et au final je m'en suis mieux sorti que certains [...]. Parce que pour moi, avant, jouer de la bossa nova c'était... Je ne savais même pas ce que c'était que c'te musique de toute façon. »

C'est aussi ce qu'on retrouve avec Stéphane (24 ans, guitariste depuis 11 ans et inscrit en école de musique pour sa $3^{\mathrm{e}}$ année), qui explique partir « dans tous les sens » depuis son entrée à l'école :

«Quand je suis arrivé à l'école, j'étais pas super ouvert, c'est plus après... Ils ont un peu un programme à l'école qui t'incite... Enfin, c'est pas qui t'incite, mais ça m'a fait ressortir l'importance d'avoir une pratique musicale vachement large. Du coup, ça fait un ou deux ans que je pars dans tous les sens [...]. Maintenant, je suis bien ouvert à tous les styles. Tu vois, actuellement j'ai un groupe de hardcore, un groupe de rap et deux groupes plutôt orientés jazz, quoi. »

II faut dire que tous les enseignants insistent lourdement auprès de leurs élèves sur cette nécessité de s'《 ouvrir » à la pratique de différents genres musicaux, savoir jouer « de
For Florent (24, has played the guitar for 9 years; in his second year of music school), it was bossa nova he "opened" up to:

"When I started at the school, I told myself it was much better to widen my interests rather than concentrate on a particular thing, in fact. It's more about styles [...] Like opening up [...] We put on a Latin music concert. My challenge at the start of last year was to say to myself, if at the end of the year I can play Latin music, and I've at least got the rhythm and everything, I'll be really pleased with myself [...]. I was scared of just messing up, but in the end I did better than some [...] Because before that, well [...] I didn't even know what bossa nova was really."

We come across this again with Stéphane-24, who has played the guitar for 11 years and is in his 3rd year of music school-who talks about "going off in all directions" since starting at the school:

"When I started at the school, I wasn't very open, it was more afterwards [...] They have a bit of a programme at the school that encourages you [...] In the end, that's not what encourages you, but it made me see the importance of playing a very wide range of music. So l've been playing in lots of different directions for a year or two [...]. Now I'm very open to all styles. You know, l've got a hardcore group, a rap group, and two more jazz-oriented groups."

It must be said that all the teachers are very keen on the need for their students to be "open" to playing different genres of music, to know how to play "a bit of everything," and that this 
tout » constituant une compétence indispensable au «bon » musicien ${ }^{13}$. Ainsi, « ouvrir les oreilles» des élèves «sur autre chose » constitue le premier objectif de l'enseignement dispensé par l'école selon cet enseignant :

" Ils [les élèves] arrivent avec un projet, c'est-à-dire "moi j'écoute du AC/DC", "moi j'écoute du Metallica", "moi j'écoute My Chemical Romance", des trucs comme ça, donc un truc quoi, et qui, après, essaient de s'y mettre. Et moi, je ne pousse pas forcément au développement, je veux qu'ils aient du plaisir dans leur pratique, qu'ils arrivent à peu près à ce qu'ils voulaient, quoi, pour ensuite les diriger... Leur ouvrir les oreilles sur autre chose. C'est ça, pour moi, le but d'un premier cycle, tu vois? Je dirais que, dans un premier cycle, il faut faire de l'initiation à l'instrument et au groupe évidemment, mais surtout, faire découvrir des choses, à travers leur univers au début et, ensuite, commencer un peu à ouvrir pour savoir s'ils sont prêts à s'ouvrir ou pas. S'ils ne sont pas prêts à s'ouvrir et qu'ils veulent rester dans un truc hyper fermé, ça devient des autistes de la musique donc... Non quoi ! »

Cette incitation des enseignants à jouer « de tout » est quasi permanente dans l'institution, mais s'observe à différents degrés selon les cours. Elle s'effectue de manière assez explicite dans le cadre du cours de «culture musicale » dispensé dans les deux écoles étudiées et dont l'objectif affiché est, pour reprendre les propos d'un enseignant, « de faire découvrir un maximum de choses différentes, d'élargir

13 Faisant en cela écho au constat déjà réalisé par Marc Perrenoud selon lequel : «On retrouve très régulièrement en entretien, mais aussi dans l'observation des activités pédagogiques ou même dans la presse spécialisée (Guitares et claviers, Batteur magazine, etc.) l'idée que pour devenir un "bon musicien" il faut savoir tout jouer » (Perrenoud $2013: 30$ ) constitutes an indispensable skill for a "good" musician"13. Thus, "opening students" ears' to "something new" is the main objective of teaching provided by the school according to this teacher:

"They [students] arrive with a plan, such as 'I listen to AC/DC,' 'I listen to Metallica,' 'I listen to My Chemical Romance,'-things like that, you know-something that they then set about trying out. And I don't necessarily force them to move forward; I want them to enjoy playing, so that they more or less achieve what they wanted in order to then guide them [...] Open their ears to other things. That's the aim of the first cycle to my mind, you know? l'd say that in the first cycle it's important to provide an introduction to the instrument and to the group, of course; but above all, it's important to start with to let students discover things via their own world, and then to start to open up a bit to know if they're ready to open themselves up or not. If they're not ready to open themselves up and they want to stay focused on something very closed, well that's becoming musically autistic, so $[\ldots]$ no?"

Teachers' encouragement to play "a bit of everything" is fairly consistent throughout the establishment, but to varying degrees depending on the class. It is carried out in a fairly explicit manner in the context of "music culture" classes given in the two schools studied, which have the stated aim of, in the words of one teacher, "for students to discover as many

13 This echoes the observation already made by Marc Perrenoud according to which: "We regularly come across the idea-in interviews, but also in observing pedagogic activities or in the specialized press (Guitares et claviers-Guitars and Keyboards-Batteur magazine-Drummer Magazine, etc.) that to become a 'good musician' you must know how to play everything" (Perrenoud 2013: 30) 
son univers musical » (enseignant, 30 ans). Elle passe aussi par les morceaux imposés par les enseignants qui visent parfois à initier leurs élèves à la pratique d'un nouveau genre musical (« Le blues, je dois le donner en cours maintenant, je l'impose. Y'a très peu d'élèves qui me disent qu'ils veulent faire du blues. Je dois l'imposer parce que ça me paraît important qu'ils sachent faire du blues » [enseignant, 39 ans]). Enfin, elle se manifeste de manière plus diffuse dans les propos des enseignants qui évoquent régulièrement dans les différents cours l'importance de jouer « de tout», de ne pas « s'enfermer » dans un style.

À travers cette modification du répertoire stylistique des élèves, c'est plus largement toute une transformation du rapport à la musique qui se donne à voir. L'ouverture de l'activité musicale des élèves rend plus largement compte du développement d'un intérêt pour la pratique en elle-même, relativement indépendant de la musique produite. C'est ce lien entre l'« ouverture » musicale et le rapport formel à la pratique qu'illustre bien Florent lorsqu'il dit jouer différents styles parce qu'il aime « faire de la musique en général » :

« Avant, je me trouvais dans un style, donc j'aimais bien être dedans. Le métal, le punk, ça m'allait bien. Puis, au final, de faire de la musique avec plein de gens différents, je me suis rendu compte que ce que j'aimais par-dessus tout, c'était faire de la musique. J'ai des affinités avec certains types de musique, mais j'aime vraiment faire de la musique en général. » different things as possible, to expand their musical universe" (teacher, 30 years old). It can also be seen in the pieces set by teachers who sometimes aim to introduce their students to playing a new music style ("The blues - I have to give lessons on it now, I enforce it. Very few students tell me they want to play blues. I have to enforce it because I think it's very important that they know how to play the blues" [teacher, 39]). Finally, it can be seen most widely in the remarks of teachers of different classes who regularly evoke the importance of playing "a bit of everything," and not "closing yourself off" in one style.

Through this change in students' stylistic repertoire, we see a bigger transformation of the relationship to music. The opening up of students' musical activity is evidence more generally of the development of an interest in the practice in itself that is relatively independent of the music produced. It is this link between a musical "opening up" and the formal relationship to playing that Florent illustrates well when he says that he plays different styles because he likes "playing music in general":

"Before, I found myself in a style, so I really liked getting into it. Metal, punk, that suited me. Then, in the end, through playing music with lots of different people, I realised that what I liked most of all was playing music. I have affinities with certain types of music, but I really like playing music in general." 
En fait, si Florent aime jouer « de tout », c'est parce qu'il aime jouer avant tout. L'intérêt pour le jeu prime, à ses yeux, sur l'intérêt pour ce qui est joué.

Le lien entre « ouverture » de la pratique à différents genres musicaux et rapport formel à l'activité musicale se manifeste aussi dans le rejet des élèves pour les appellations stylistiquement marquées. II n'y a en effet que les autodidactes pour revendiquer une appartenance exclusive à un registre musical («moi je suis un rockeur » nous dira Hakim, par exemple). Pour leur part, les élèves refusent de se considérer comme « guitariste rock » ou « guitariste métal »14. Ils préfèrent se définir comme «musicien » ou, dans une moindre mesure, " guitariste », catégorie qui renvoie plus largement à la pratique (faire de la musique ou faire de la guitare) qu'à la musique produite, exprimant en cela leur intérêt pour l'activité musicale en elle-même. Aurélien refuse ainsi la dénomination de " guitariste rock » car elle ne rend pas compte de son intérêt pour la « guitare en soi »:

Enquêteur. - Et est-ce que tu te définirais comme un guitariste rock?

Aurélien. - ... Guitariste rock, je pense que ce n'est pas... Enfin, moi, ce que j'essaye de faire en ce moment, c'est plus de faire de la guitare en soi [...] J'aime quand

14 Dans cette idée, on peut se demander si le constat de Perrenoud selon lequel "les musiciens pour qui "le jazz" constitue une ressource identitaire spécifique, ou même une catégorie cognitive et discursive cohérente et régulièrement mobilisée, ne sont pas si courants " (Perrenoud 2013

33) ne doit pas être mis en lien avec la forte institutionnalisation de son apprentissage depuis les années 1980 (Coulangeon, 1999).
In fact, while Florent likes playing "a bit of everything," it is ultimately because he likes playing full stop. The importance of playing, in his view, takes priority over the importance of what is played.

The link between the "opening up" of the practice to different musical genres and the formal relationship to musical activity can also be seen in students' rejection of stylistically determined names. It is, in fact, only the self-taught musicians who claim exclusive adherence to a music style ("I'm into rock" Hakim will say, for example). For their part, students refuse to see themselves as a "rock" or "metal" guitarists. ${ }^{14}$ They prefer to define themselves as "musicians" or, in a more specific sense, "guitarists"-more general categories that refer to the practice (playing music or playing the guitar) rather than to the music produced, thus expressing their interest in the musical activity in itself. Aurélien thus rejects the prevalence of the term "rock guitarist" since it fails to take account of his interest in the "guitar in itself":

Interviewer - Would you define yourself as a rock guitarist?

Aurélien - [...] Rock guitarist, I don't think that's [...] । mean, what I try to do at the moment, is more about playing the guitar in itself [...] Yeah, I love rock, but I don't think it's very good to limit yourself to a genre. I think the more genres

14 From this idea, the question arises as to whether Perrenoud's observation that 'musicians for whom 'jazz' forms a specific source of identity, or even a coherent and frequently used cognitive and discursive category are not that common" (Perrenoud 2013: 33) could be linked to the strong institutionalization of music learning since the 1980s (Coulangeon 1999). 
même vraiment le rock, mais je pense que ce n'est pas très bien de se limiter à un genre. Je pense que plus on met de truc et mieux c'est, plus c'est riche quoi [...] Donc guitariste rock, je ne pense pas.

Dans le même ordre d'idées, tout ce qui pourrait signifier une appartenance marquée à un genre musical quelconque, que ce soit d'ordre vestimentaire (poignets de force pour les « métalleux »...) ou corporel (dreadlocks, piercings...), tend à disparaître avec l'entrée en école de musique afin, comme l'observe Marc Perrenoud à propos des musicos, de présenter " une apparence proche de la "normalité", ce qui leur permet de se détacher d'un marquage "idiomatique" et d'apparaître comme des spécialistes de leur instrument stylistiquement polyvalents » (Perrenoud 2007 : 49). En somme, à travers cette ouverture musicale des élèves, c'est un rapport formel à la pratique qui se fait jour : la pratique existe en ellemême et pour elle-même, presque indépendamment de la musique produite. En cela, l'ouverture rend bien compte de la construction, par l'école, d'une nouvelle manière d'appréhender la pratique, en rupture avec celle que les élèves s'étaient construite en dehors de l'institution.

De manière connexe et pour brièvement prolonger les réflexions évoquées en introduction, la mise en évidence du lien entre manière de se qualifier, rockeur ou musicien, et rapport à la musique nous amène à interroger la pertinence méthodologique d'une appréhension des musiciens à travers les genres musicaux. Différentes recherches portant sur les musiciens de « rock », de « rap », de « jazz », etc., expliquent en effet construire leur population sur la base you master the better it is, the more rewarding it is, isn't it [...] So no, rock guitarist, I don't think so.

Along similar lines, all that might signify belonging to any type of music style-whether this be clothing (arm bands for "metal heads", etc.) or physical features (dreadlocks, piercings, etc.) - tends to disappear once a musician goes to music school in a desire to have a "more 'normal' appearance," as Marc Perrenoud notes. "This allows them to disassociate from 'idiomatic' markings, to appear instead like stylistically versatile specialists of their instrument" (Perrenoud 2007: 49). On balance, through this musical opening in students, what emerges is a formal relationship to playing music: the practice exists in itself and for itself, almost independently of the music produced. The opening up thus explains music schools' construction of a new way of apprehending playing music that breaks with the one students had built outside the establishment.

Following a similar idea, and to briefly expand on the reflections mentioned in the introduction, the detection of the link between the way of describing oneself as a "rocker" or musician and the relationship to music leads us to query the methodological relevance of an understanding of musicians through music genres. Various research into "rock," "rap," "jazz" musicians etcetera indeed states that its interviewee population was built based on respondents' declarations who define themselves 
des déclarations des enquêtés se définissant comme « rockeurs », « rappeurs », « jazzmen », etc. face au sociologue. Cependant, comme nous venons de le voir, se déclarer comme appartenant à une famille musicale n'est pas socialement neutre ; le sentiment d'appartenance à un genre musical, ou tout au moins la déclaration, face au chercheur, de ce sentiment d'appartenance, est beaucoup plus rare chez les musiciens formés au sein d'une institution d'enseignement musical et, plus largement, chez ceux qui ont développé un rapport formel à la musique. Ainsi, en interrogeant des instrumentistes qui se présentent comme appartenant à un genre musical spécifique, un chercheur opère une sélection, parfois non consciente, parmi les instrumentistes de musiques « populaires » contemporaines. Si l'on ajoute à cela la difficulté à définir objectivement les genres musicaux « populaires » contemporains ${ }^{15}$, et donc à cerner la population qui y correspond, on ne peut considérer qu'avec prudence les tentatives d'établir les caractéristiques et spécificités des musiciens de « rock », de « rap » ou de

«jazz ».

\section{Conclusion}

Face à une tendance de la sociologie à prendre les genres musicaux comme principale ligne de partage entre les musiciens, nous avons cherché ici à démontrer que le mode de

15 Ainsi, pour prendre l'exemple des travaux sur le rock, Emmanuel Brand souligne : "II n'existe plus aujourd'hui de "colloques", de "rencontres", de "mémoires", ou d'articles et de thèses (de quelque discipline qu'il s'agisse) qui ne commencent par un discours ou une introduction embarrassée sur la définition des musiques "rock" » (Brandl 2009 : 19). to the sociologist as "rockers," "rappers," "jazz musicians," etc. However, as we have just seen, claiming allegiance to a music family is not socially neutral; the feeling of belonging to a genre of music, or at least making this claim to a researcher is much less common in musicians who have trained at a music teaching establishment and, more generally, in those who have developed a formal relationship to music. Thus, in interviewing instrumentalists who present themselves as belonging to a specific music genre, the researcher makes asometimes unconscious - selection between instrumentalists of contemporary popular music. If we add to this the difficulty in objectively defining contemporary popular music genres ${ }^{15}$, and therefore in identifying the corresponding population, we must be very careful in considering attempts to establish the characteristics and specific features of "rock," "rap," or "jazz" musicians.

\section{Conclusion}

Compared with the tendency in sociology to treat music genres as the main dividing line between musicians, I have sought to demonstrate that the way the activity is transmitted forms an objectively divisive element in the world of playing music. At the

15 Thus, to take the example of work on rock, Emmanuel Brandl stresses: "Today we no longer have 'seminars,' 'meetings,' and 'dissertations,' or articles and theses (in whichever discipline) that begin with a confused discussion or introduction on the definition of types of 'rock' music" (Brandl 2009: 19). 
transmission de l'activité constitue un élément objectivement clivant dans l'univers de la pratique musicale. Parallèlement au fait d'être « rockeur », « jazzman » ou « rappeur », il apparaît qu'une différence fondamentale se situe au niveau des modes de formation. Parce que les différents modalités de transmission, scolaires et non scolaires, ne construisent pas les mêmes rapports à la pratique, les mêmes manières de faire et de penser la musique, élèves et autodidactes apparaissent comme deux types de musiciens différents. Le fait que les musiciens passés par une institution d'enseignement musical sachent « travailler », « comprennent » ce qu'ils jouent et se soient « ouverts » à la pratique de différents styles musicaux constitue autant d'indices du rapport à la pratique spécifique construit par l'école, en décalage avec celui qui préexistait à leur entrée dans l'institution. Si ce principe de division par les modes de transmission ne se substitue pas au clivage en genres musicaux, il appelle néanmoins à l'interroger. En effet, appréhendés depuis leurs modes de formation, des musiciens très éloignés esthétiquement peuvent se révéler très proches dans leur manière d'envisager la musique et sa pratique, et inversement. En cela, les modalités de transmission nous semblent constituer un principe de division moins visible, mais peut être plus profond, entre les musiciens.

Enfin, la réflexion menée dans cet article permet de souligner les limites du découpage de la sociologie par thèmes et objets d'étude. Si aucune recherche sur les musiciens n'avait jusqu'alors intégré les travaux sociologiques portant sur l'école, et plus précisément ceux mobilisant le concept de forme scolaire, pour analyser plus précisément la division same time as the fact of being a "rocker," "jazz musicians," or "rapper," it would seem that there is a fundamental difference in terms of training methods. Since the different modes of transmission-academic and non-academic-do not build the same relationship to playing, or the same ways of making and thinking about music, students and self-taught musicians appear to be two different types of musician. The fact that musicians who attend a music teaching institution know how to "work," "understand" what they play, and are "open" to playing different styles of music are equally indications of a specific relationship to playing that is formed by the school and that is irreconcilable with that which pre-existed their entry into the establishment. While this principle of division via transmission methods may not replace the divide along music genre lines, it nevertheless invites us to query it. In fact, when perceived in terms of how they have been trained, musicians who are very far apart aesthetically can prove to be very similar in the way they consider music and playing music, and vice versa. Thus, transmission methods appear to constitute a less visible but perhaps deeper division between musicians.

Finally, the thinking explored in this article highlights the limitations of dividing sociology up into themes and research subjects. The fact that research on musicians, and more specifically that employing the concept of school form, has not previously incorporated sociological studies on school to more accurately analyse the division of musicians that 
des musiciens induite par les modes de transmission pourtant aperçue par certains chercheurs, c'est en partie du fait de la tendance à une surspécialisation de la recherche en sociologie. Comme l'a déjà souligné Bernard Lahire : « À trop vouloir se centrer et se concentrer sur un univers ou un sous-univers singuliers, l'analyste finit par louper la cible en oubliant qu'une partie de la "vérité" (raison d'être, principes structurants ou explicatifs) des pratiques se trouve hors de l'univers ou du sous-univers en question » (Lahire 2012). Face à cette limite du découpage actuel de la discipline, l'appel à la mise en œuvre de travaux se situant au croisement de différents domaines de la sociologie, aussi louable soit-il, nous apparait néanmoins insuffisant, dans la mesure où il revient toujours à reconnaître, et donc à maintenir, l'existence de ces frontières internes alors qu'elles nous semblent justement être à l'origine du problème. Nous considérons pour notre part que la sociologie gagnerait à abandonner cette organisation par thèmes et objets d'étude au profit d'une organisation centrée sur les questions et problématiques traitées. Nous pensons en effet que bien plus que l'objet d'étude tel qu'il apparait dans le monde social, c'est le questionnement, la problématique qui définit réellement une recherche. Le regroupement des recherches par questions de recherche plutôt que par objets serait, à notre sens, bien plus favorable aux échanges entre chercheurs et donc à la réalisation de progrès de connaissance. II aurait par ailleurs aussi le mérite d'affirmer l'ambition scientifique de la discipline dont on a malheureusement parfois l'impression, à la lecture de certains travaux, qu'elle relève davantage d'un goût pour ses objets d'étude que pour l'étude de ses objets. is brought about by transmission methods-although this has been perceived by some researchers-can partly be explained by the tendency towards the specialization of research in sociology. As Bernard Lahire has pointed out: "In a desire to concentrate on a single sphere or sub-sphere, analysis ends up missing the target by forgetting that part of the 'truth' (the raison d'être or structuring or explanatory principles) of practices is located outside the sphere or subsphere in question" (Lahire 2012). In view of this limitation in terms of the current dividing up of the discipline, I find the call to carry out work located at the intersection of different fields of sociology-as laudable as it may be-insufficient insofar as it always comes back to the issue of recognizing, and therefore maintaining, the existence of these internal borders while they appear to me to be the very cause of the problem. I believe that sociology would benefit from abandoning this organization based on themes and subjects in favour of an organization centred on the questions and problems dealt with. Indeed, I feel that a piece of research is defined far more by its line of inquiry or problem than it is by the research subject such as it appears in the social world. Regrouping research according to research question rather than subject would be, in my opinion, much more favourable to exchanges between researchers and therefore to achieving progress in knowledge. Furthermore, it would have the benefit of confirming the scientific ambition of the discipline-concerning which, on reading certain works, we sometimes have the impression, unfortunately, that it is more a question of an appetite for the subjects of its research than it is for the research of its subjects.

Rémi Deslyper Université Lumière Lyon 2/Éducation,Cultures, Politiques 


\section{Références bibliographiques}

Baudelot Christian, Cartier Marie, Détrez Christine (1999). Et pourtant ils lisent... Paris, Seuil.

Bertrand Julien (2008). La Fabrique des footballeurs. Analyse sociologique de la construction de la vocation, des dispositions et des savoir-faire dans une formation au sport professionnel (thèse de doctorat en sociologie). Lyon, Université Lumière Lyon 2.

BouRdieu Pierre (1975). «L'invention de la vie d'artiste ». Actes de la recherche en sciences sociales, 2 : 67-93.

BOURDIEU Pierre (1984) [1981]. « Comment peut-on être sportif ?». Questions de sociologie. Paris, Minuit : 173-195.

BRANDL Emmanuel (2009). L'Ambivalence du rock. Entre subversion et subvention. Une enquête sur l'institutionnalisation des musiques populaires. Paris, L'Harmattan.

CoulAngeOn Philippe (1999). «Les musiciens de jazz : les chemins de la professionnalisation ». Genèses, 36 : 54-68.

Coulangeon Philippe \& RAVEt Hyacinthe (2003). « La division sexuelle du travail chez les musiciens français ». Sociologie du travail, 45(3) : 361384

Delbos Geneviève \& JoRION Paul (1984). La Transmission des savoirs. Paris, MSH.

DeslyPER Rémi (2009). "Des types d'apprentissage aux formes de pratique. L'exemple de l'institutionnalisation de l'enseignement de la guitare électrique ». SociologieS. [En ligne] http://journals.openedition. org/sociologies/2834 [consulté le 15 mars 2018].

\section{References}

Baudelot Christian, Cartier Marie, Détrez Christine (1999). Et pourtant ils lisent... Paris, Seuil.

BERTRAND Julien (2008). La Fabrique des footballeurs. Analyse sociologique de la construction de la vocation, des dispositions et des savoir-faire dans une formation au sport professionnel (PhD dissertation, Sociology). Lyon, Université Lumière Lyon 2.

BOURDIEU Pierre (1987) [1975]. "The Invention of Artist's Life.” English translation by Erec R. Koch. Yale French Studies, 73: 75-103.

BOURDIEU Pierre (1993) [1981]. "How can one be a sportsman." In BouRdieu Pierre. Sociology in Question. English translation by Richard Nice. London, Sage: 117-131.

BRANDL Emmanuel (2009). L'Ambivalence du rock. Entre subversion et subvention. Une enquête sur l'institutionnalisation des musiques populaires. Paris, L'Harmattan.

CoulANGeON Philippe (1999). "Les musiciens de jazz: les chemins de la professionnalisation." Genèses, 36: 54-68.

Coulangeon Philippe \& Ravet Hyacinthe (2003). "La division sexuelle du travail chez les musiciens français ». Sociologie du travail, 45(3): 361384.

Delbos Geneviève \& JoRION Paul (1984). La Transmission des savoirs. Paris, MSH.

DESLYPER Rémi (2009). "Des types d'apprentissage aux formes de pratique. L'exemple de l'institutionnalisation de l'enseignement de la guitare électrique." SociologieS. [On line] http://journals.openedition.org/ sociologies/2834 [accessed on 15 March 2018]. 
DesLYPER Rémi (2013). "Des "écoles de l'autodidaxie" ? L'enseignement des "musiques actuelles" au prisme de la forme scolaire ". Revue française de pédagogie, 185 : 49-58.

DeslyPER Rémi (2018a). Les Élèves des écoles de « musiques actuelles". La transformation d'une pratique musicale. Lille, Presses universitaires du Septentrion.

DESLYPER Rémi (2018b). " Les conditions sociales d'une vocation tardive. Le cas des apprentis musicos des écoles de "musiques actuelles" ». Sociétés contemporaines, 111 : 99-125.

Donnat Olivier (1996). Les Amateurs. Enquête sur les pratiques artistiques des Français. Paris, DEPS.

ELoY Florence (2015). Enseigner la musique au collège. Cultures juvéniles et culture scolaire. Paris, PUF.

FAURE Sylvia (2000). Apprendre par corps. Socio-anthropologie des techniques de danse. Paris, La Dispute.

FaURe Sylvia \& Garcia Marie-Carmen (2005). Culture hip-hop, jeunes des cités et politiques publiques. Paris, La Dispute.

FABIANI Jean-Louis (1986). « Carrières improvisées : théories et pratiques de la musique de jazz en France ". In MouLIN Raymonde (dir.). Sociologie de l'Art. Paris, La Documentation française : 231-245.

Françols Pierre (2008). «La formation musicale ». In Françols Pierre (dir.). La Musique. Une industrie, des pratiques. Paris, La Documentation française : 35-46.

Green Lucy (2002). How Popular Musicians Learn. A Way Ahead for Music Education. Londres/New York, Ashgate Press.
Deslyper Rémi (2013). "Des 'écoles de l'autodidaxie'? L'enseignement des 'musiques actuelles' au prisme de la forme scolaire." Revue française de pédagogie, 185: 49-58.

DesLyper Rémi (2018a). Les Élèves des écoles de "musiques actuelles." La transformation d'une pratique musicale. Lille, Presses universitaires du Septentrion.

DesLyPER Rémi (2018b). "Les conditions sociales d'une vocation tardive. Le cas des apprentis musicos des écoles de 'musiques actuelles'." Sociétés contemporaines, 111: 99-125.

Donnat Olivier (1996). Les Amateurs. Enquête sur les pratiques artistiques des Français. Paris, DEPS.

ELoY Florence (2015). Enseigner la musique au collège. Cultures juvéniles et culture scolaire. Paris, PUF.

FAURE Sylvia (2000). Apprendre par corps. Socio-anthropologie des techniques de danse. Paris, La Dispute.

FAURE Sylvia \& GARCIA Marie-Carmen (2005). Culture hip-hop, jeunes des cités et politiques publiques. Paris, La Dispute.

FABIANI Jean-Louis (1986). "Carrières improvisées: théories et pratiques de la musique de jazz en France." In MouLIN Raymonde (ed.). Sociologie de l'Art. Paris, La Documentation française: 231-245.

Françols Pierre (2008). "La formation musicale." In Françols Pierre (ed.). La Musique. Une industrie, des pratiques. Paris, La Documentation française: $35-46$.

Green Lucy (2002). How Popular Musicians Learn. A Way Ahead for Music Education. London/New York, Ashgate Press. 
LAHIRE Bernard (1993a). Culture écrite et inégalités scolaires. Sociologie de l'« échec scolaire » à l'école primaire. Lyon, Presses universitaires de Lyon.

LAHIRE Bernard (1993b). La Raison des plus faibles. Rapport au travail, écritures domestiques et lectures en milieux populaires. Lille, Presses universitaires de Lille.

LAHIRE Bernard (1998). L'Homme pluriel. Les ressorts de l'action. Paris, Nathan.

LAHIRE Bernard (2012). " Des effets délétères de la division scientifique du travail sur l'évolution de la sociologie ». SociologieS. [En ligne] http:// journals.openedition.org/sociologies/3799 [consulté le 15 mars 2018].

LEGON Tomas (2014). À la recherche du plaisir culturel. La construction des avis a priori en musique et cinéma chez le public lycéen (thèse de doctorat en sociologie). Paris, EHESS.

Legon Tomas (2016). " Les adolescents ont-ils des problèmes de mémoire ? Repérer et retenir les références objectives associées aux œuvres ». In Delaporte Chloé, Graser Léonor, Pequignot Julien (dir.). Penser les catégories de pensée. Arts, cultures et médiations. Paris, L'Harmattan : 155-170.

LeHMANn Bernard (2002). L'Orchestre dans tous ses éclats. Ethnographie des formations symphoniques. Paris, La Découverte.

Millet Mathias (2003). Les Étudiants et le travail universitaire. Lyon, Presses universitaires de Lyon.

Perrenoud Marc (2007). Les Musicos. Ethnographie des musiciens ordinaires. Paris, La Découverte.
LAHIRE Bernard (1993a). Culture écrite et inégalités scolaires. Sociologie de l'échec scolaire" à l'école primaire. Lyon, Presses universitaires de Lyon.

LAHIRE Bernard (1993b). La Raison des plus faibles. Rapport au travail, écritures domestiques et lectures en milieux populaires. Lille, Presses universitaires de Lille.

LAHIRE Bernard (2011). The Plural Actor. English translation by David Fernbach. Cambridge, Polity Press.

LAHIRE Bernard (2012). "Des effets délétères de la division scientifique du travail sur l'évolution de la sociologie ». SociologieS. [On line] http:// journals.openedition.org/sociologies/3799 [accessed on 15 March 2018].

LEGON Tomas (2014). À la recherche du plaisir culturel. La construction des avis a priori en musique et cinéma chez le public lycéen (PhD dissertation, Sociology). Paris, EHESS.

LEGON Tomas (2016). "Les adolescents ont-ils des problèmes de mémoire? Repérer et retenir les références objectives associées aux œuvres." In Delaporte Chloé, Graser Léonor, Pequignot Julien (eds.). Penser les catégories de pensée. Arts, cultures et médiations. Paris, L'Harmattan: $155-170$

LeHMANN Bernard (2002). L'Orchestre dans tous ses éclats. Ethnographie des formations symphoniques. Paris, La Découverte.

Millet Mathias (2003). Les Étudiants et le travail universitaire. Lyon, Presses universitaires de Lyon.

Perrenoud Marc (2007). Les Musicos. Ethnographie des musiciens ordinaires. Paris, La Découverte. 
Perrenoud Marc (2008). «Passage à l'acte : de la réception active à la pratique musicale chez les jeunes amateurs ». In GAUDEZ Florian (dir.). Les Arts moyens aujourd'hui. Paris, L'Harmattan : 305-314.

Perrenoud Marc (2012a). “"Musicien de jazz" : une catégorie familière à l'épreuve du terrain ". In BENGHOZI Pierre-Jean \& PARIS Thomas (dir.). Howard Becker et les mondes de l'art. Paris, Éditions de l'École polytechnique : 27-34

Perrenoud Marc (2012b). «Penser, dire et faire la musique : ethnothéories musicales des instrumentistes ordinaires ». In BRANDL Emmanuel, Prévost-Thomas Cécile, Ravet Hyacinthe (dir.). 25 ans de sociologie de la musique en France. Tome 2 : Pratiques, œuvres, interdisciplinarité. Actes $d u X I I^{e}$ Colloque international de sociologie de l'art (GDRI OPuSCNRS, La Sorbonne, 6-8 novembre 2008). Paris, L'Harmattan : 105-114.

PolıAK Claude F. (1992). La Vocation d'autodidacte. Paris, L'Harmattan.

THIN Daniel (1998). Quartier populaire. L'école et les familles. Lyon, Presses universitaires de Lyon.

VINCENT Guy (1980). L'École primaire française. Étude sociologique. Lyon, Presses universitaires de Lyon.

VinCENT Guy, LAHIRE Bernard, Thin Daniel (1994). « Sur I'histoire et la théorie de la forme scolaire ". In VINCENT Guy (dir.). L'Éducation prisonnière de la forme scolaire ? Scolarisation et socialisation dans les sociétés industrielles. Lyon, Presses universitaires de Lyon : 11-48.

WACQUANT Loïc (1989). «Corps et âme ». Actes de la recherche en sciences sociales, $80: 33-67$

WeBER Max (1997). Sociologie de la musique. Les fondements rationnels et sociaux de la musique. Traduit de l'allemand par Jean Molino et Emmanuel Pedler. Paris, Métailié.
PeRRENOUd Marc (2008). "Passage à l'acte: de la réception active à la pratique musicale chez les jeunes amateurs." In GAUDEZ Florian (ed.). Les Arts moyens aujourd'hui. Paris, L'Harmattan: 305-314.

Perrenoud Marc (2012a). “'Musicien de jazz': une catégorie familière à l'épreuve du terrain." In BENGHOZI Pierre-Jean \& PARIS Thomas (eds.). Howard Becker et les mondes de l'art. Paris, Éditions de l'École polytechnique: $27-34$.

Perrenoud Marc (2012b). "Penser, dire et faire la musique: ethnothéories musicales des instrumentistes ordinaires." In BRANDL Emmanuel, Prévost-Thomas Cécile, Ravet Hyacinthe (eds.). 25 ans de sociologie de la musique en France. Tome 2: Pratiques, œuvres, interdisciplinarité. Actes du XIle colloque international de sociologie de l'art (GDRI OPuS CNRS, La Sorbonne, 6-8 novembre 2008). Paris, L'Harmattan: 105-114.

Polıak Claude F. (1992). La Vocation d'autodidacte. Paris, L'Harmattan.

THIN Daniel (1998). Quartier populaire. L'école et les familles. Lyon, Presses universitaires de Lyon.

VinCENT Guy (1980). L'École primaire française. Étude sociologique. Lyon, Presses universitaires de Lyon.

Vincent Guy, LaHIRE Bernard, Thin Daniel (1994). "Sur l'histoire et la théorie de la forme scolaire." In VINCENT Guy (ed.). L'Éducation prisonnière de la forme scolaire? Scolarisation et socialisation dans les sociétés industrielles. Lyon, Presses universitaires de Lyon: 11-48.

WACQUANT LoÏc (1989). "Corps et âme." Actes de la recherche en sciences sociales, 80 : 33-67.

Weber Max (1958). The Rational and Social Foundations of Music. English translation by Don Martindale, Johannes Riedel and Gertrude Neuwirth. London/Amsterdam, Southern Illinois University Press/Carbondale and Edwardsville/Feffer and Simons. 